\title{
1 KLF17 promotes human naïve pluripotency but is not required for its establishment
}

Rebecca A. Lea ${ }^{1}$, Afshan McCarthy ${ }^{1}$, Stefan Boeing ${ }^{2}$, Kathy K. Niakan ${ }^{1,3}$ *

${ }^{1}$ Human Embryo and Stem Cell Laboratory, The Francis Crick Institute, 1 Midland Road, London NW1 1AT, UK

${ }^{2}$ Bioinformatics and Biostatistics Service, The Francis Crick Institute, 1 Midland Road, London NW1 1AT, UK

${ }^{3}$ The Centre for Trophoblast Research, Department of Physiology, Development and Neuroscience, University of Cambridge, Cambridge CB2 3EG, UK

*Correspondence: kkn21@cam.ac.uk

\section{Summary statement}

Investigating KLF17 in human pluripotency reveals that it is sufficient, but not necessary, to establish naïve hESCs. We posit that KLF17 is a peripheral regulator, like KLF2 in the mouse.

\section{Abstract}

Current knowledge of the transcriptional regulation of human pluripotency is incomplete, with lack of inter-species conservation observed. Single-cell transcriptomics of human embryos previously enabled us to identify transcription factors, including the zinc-finger protein KLF17, that are enriched in the human epiblast and naïve hESCs. Here we show that KLF17 is expressed coincident with the known pluripotency factors NANOG and SOX2 across human blastocyst development. We investigate the function of KLF17 in pluripotency using primed and naïve hESCs for gain- and loss-of-function analyses. We find that ectopic expression of KLF17 in primed hESCs is sufficient to induce a naïvelike transcriptome and that KLF17 can drive transgene-mediated resetting to naïve pluripotency. This implies a role for KLF17 in establishing naïve pluripotency. However, CRISPR-Cas9-mediated knockout studies reveal that KLF17 is not required for naïve pluripotency acquisition in vitro. Transcriptome analysis of naïve hESCs identifies subtle effects on metabolism and signalling following KLF17 loss of function, and possible redundancy with the related factor, KLF5. Overall, we show that KLF17 is sufficient, but not necessary, for naïve pluripotency under the given in vitro conditions.

\section{Key words:}

Human embryonic stem cells, naïve pluripotency, epiblast, KLF17, KLF factors 


\section{Introduction}

Model organisms such as the mouse have allowed for the identification of molecular mechanisms that regulate early mammalian development (Rossant, 2016), some of which are conserved in humans (Gerri et al., 2020). Despite the continued importance of comparative studies in mouse and other organisms, some aspects of early development such as developmental timing, chromatin accessibility and transcription factor function are distinct compared to humans (Niakan and Eggan, 2013, Fogarty et al., 2017, Gao et al., 2018). In particular, the advent of single-cell sequencing technologies has allowed in-depth transcriptomic analysis of human embryos, revealing a number of molecular differences compared to the mouse (Yan et al., 2013, Blakeley et al., 2015, Petropoulos et al., 2016, Stirparo et al., 2018). Our previous analysis highlighted that a number of genes thought of as canonical pluripotency-associated factors in the mouse, including KLF2, ESRRB and BMP4 (Blakeley et al., 2015), are not expressed in the pluripotent epiblast (EPI) of the human pre-implantation embryo, which forms the embryo proper. Conversely, we also highlighted a number of genes that are specifically enriched in the human EPI, but not expressed in the pluripotent cells of the mouse embryo, including transcriptional regulators and signalling components (Blakeley et al., 2015).

Of these human EPI-enriched genes, the zinc finger DNA-binding protein KLF17 has drawn considerable interest. KLF17 is one of 11 human paralogues of the Krüppel-like transcription factor family involved in development, which includes KLF4, a commonly used reprogramming factor (Takahashi and Yamanaka, 2006) and KLF2, a known pluripotency regulator in the mouse (Hall et al., 2009). Given the lack of KLF2 expression in the human EPI, it is interesting to speculate that KLF17 might function in a similar way. Indeed, the expression patterns of KLF2 and KLF17 in the human embryo are diametrically opposite to those of Klf2 and Klf17 in the mouse embryo (Yan et al., 2013, Blakeley et al., 2015). While Klf17 appears to be maternally deposited in the mouse zygote and its expression is abolished around the 8-cell stage, KLF17 is dramatically upregulated in the 8-cell human embryo, following embryonic genome activation (EGA). Conversely, KIf2 is expressed from the 2-cell stage, corresponding to mouse EGA, and continues through to the blastocyst stage, but human KLF2 is expressed only pre-EGA, in the zygote to 4-cell embryo. The human KLF17 and KLF2 sequences share $\sim 60 \%$ homology across the $\mathrm{C}$-terminal region containing the functional $\mathrm{C}_{2} \mathrm{H}_{2}$-type zinc-finger domains. KLF17 and mouse KLF2 also have additional homologous regions ( $50 \%)$ throughout the protein, including part of a region in mouse KLF2 annotated as a protein-protein interaction domain, which may contribute to regulation and/or functional specificity. Furthermore, in mouse embryonic stem cells (mESCs), the triple knockout of KIf2, KIf4 and KIf5 can be rescued by ectopic expression of human KLF17, but not mouse Klf17 (Yamane et al., 2018). Finally, the human and mouse KLF17 protein sequences have less similarity overall than other pairs of KLF orthologues (van Vliet et al., 2006). This is all suggestive of rapid, divergent evolution of the human and mouse KLF genes and a potential switching of their function between species. tumour suppressor by interacting with TGFB/SMAD signalling (Ali et al., 2015b) and p53 (Ali et al., 
2015a) and inhibiting epithelial-to-mesenchymal transition (Gumireddy et al., 2009, Zhou et al., 2016). Since the recognition of its human EPI-specific expression, KLF17 has been widely used as a marker of pluripotency in the human embryo (Blakeley et al., 2015, Guo et al., 2016, Shahbazi et al., 2017, Kilens et al., 2018). The expression of KLF17 throughout pre-implantation development, and in particular in pluripotent cells, is also conserved in a number of other organisms, including non-human primates (rhesus monkey, Macaca mulatta (Wang et al., 2017); common marmoset, Callithrix jacchus (Boroviak et al., 2015); and cynomolgus monkey, Macaca fascicularis (Nakamura et al., 2016)), and pig (Sus scrofa (Bernardo et al., 2018, Ramos-lbeas et al., 2019)). Intriguingly, KLF17 expression is not detectable in conventionally derived "primed" human embryonic stem cells (hESCs) (Blakeley et al., 2015, Stirparo et al., 2018), indicating that expression from EPI cells is lost during the derivation process. However, newer methods for deriving and/or culturing hESCs and human induced pluripotent stem cells (hiPSCs) in a naïve pluripotent state result in the maintenance or reinstatement of KLF17 gene activity (Theunissen et al., 2014, Guo et al., 2017, Guo et al., 2016, Liu et al., 2017, Kilens et al., 2018). This pattern of expression suggests the intriguing possibility that KLF17 acts as a transcriptional regulator of human naïve pluripotency, as exhibited in the bona fide state of the preimplantation EPI and approximated in the in vitro naïve hESC models. This hypothesis has also been explored by independent transcriptome analysis (Stirparo et al., 2018).

Studies to date have only conclusively shown that KLF17 is a marker of human pluripotency. Here, we set out to determine the function of KLF17, finding that its induced expression in conventional hESCs is sufficient, alongside naïve-permissive pluripotency conditions, to induce a complete change in phenotype from primed to naïve pluripotency. RNA-seq during the early stages of induction in primed conditions suggests that KLF17 induces this change by regulating genes involved in important signalling pathways. However, we also find that the null mutation of KLF17 in conventional hESCs is not detrimental to naïve resetting or to the growth and survival of the resulting naïve hESCs.

Altogether, this suggests that KLF17 functions to regulate genes associated with human naïve pluripotency, but that there is a degree of redundancy in vitro, such that KLF17 itself is not strictly necessary for the acquisition and maintenance of naïve hESCs.

\section{$\underline{\text { Results }}$}

\section{KLF17 expression in the human embryo is gradually restricted to the epiblast}

Detailed single-cell RNA sequencing studies highlight KLF17 as a molecular marker that is expressed in the human embryonic EPI. First, we reassessed the protein expression dynamics of KLF17 in human embryos, to investigate its distribution across the developing blastocyst. We performed immunofluorescence (IF) analysis of KLF17 alongside the canonical pluripotency factors SOX2 and NANOG in human embryos from the early to late blastocyst stage (FIG.1, S1). NANOG is the earliest known EPI-specific factor in human embryos (Kimber et al., 2008, Niakan and Eggan, 2013), while the SOX2 expression dynamic closely resembles that of KLF17 (Blakeley et al., 2015). In keeping with previous data (Kilens et al., 2018), we found that in the earliest stage examined (early day 5 postfertilisation (dpf)), KLF17 protein was detectable in every cell of the embryo (FIG.1, S1). Though the 
121 expression levels across all nuclei were heterogeneous, this widespread staining of KLF17 was

122 largely coincident with SOX2, which is also present in both the inner cell mass (ICM) and

123 trophoectoderm (TE) populations at this stage (FIG.1, S1). As blastocyst development progressed,

124 KLF17 expression was gradually restricted, with ICM enrichment by late day 5 dpf (FIG.1, S1). In

125 early day 7 dpf blastocysts, KLF17 was detectable only in the presumptive EPI cells, delineated by

126 exclusive co-staining with both SOX2 and NANOG (FIG.1, S1). Interestingly, the restriction of KLF17

127 appeared to progress more slowly than that of SOX2. By late day $5 \mathrm{dpf}$, SOX2 was only appreciably

128 expressed in the ICM and to a lesser extent in polar TE and it was completely restricted to the EPI in

129 early day 6 dpf embryos (FIG.1, S1). In contrast, there remained appreciable KLF17 protein across

130 cells of the TE in most ( 3 of 5 ) of the late day 6 dpf blastocysts analysed (FIG.1, S1). This suggests

131 that the half-life of KLF17 protein may be longer than that of SOX2, given the absence of KLF17

132 transcripts in the extraembryonic lineages of human blastocysts by single cell RNA-sequencing

133 (scRNA-seq) analysis (Blakeley et al., 2015). As reported previously, NANOG is detected only in the

134 ICM at all stages of blastocyst development (Niakan and Eggan, 2013). Despite the initial widespread

135 expression pattern of KLF17, its gradual restriction to the NANOG/SOX2 dual-positive EPI suggests

136 that it is specifically retained in the pluripotent EPI, perhaps to perform an unappreciated role in

137 pluripotency regulation or EPI development.

Induction of KLF17 promotes a naïve pluripotency-like phenotype in conventional hESCs

140 Given that KLF17 is not expressed when hESCs are cultured in the conventional, primed state, we

141 investigated the effect of ectopic overexpression of KLF17 in hESCs. We hypothesised that KLF17, 142 as a transcriptional regulator that is enriched in the naïve state (Blakeley et al., 2015, Guo et al., 143 2016, Messmer et al., 2019), might be sufficient to regulate other naïve hESC-enriched genes when 144 ectopically expressed in primed pluripotent hESCs.

146 A doxycycline (Dox)-inducible, 3' HA-tagged KLF17 transgene was introduced into hESCs by lentiviral 147 transduction (FIG.2A). Initial tests of the transduced line showed that 5 days treatment with $1 \mu \mathrm{g} / \mathrm{ml}$

148 Dox was sufficient for robust expression of KLF17 protein in almost every cell of the population

149 (FIG.2B). We therefore examined the possibility of gene expression changes in response to ectopic

$150 \mathrm{KLF} 17$ in primed culture conditions. Using quantitative reverse transcriptase-polymerase chain reaction (qRT-PCR), we analysed the expression of a number of genes identified as either naïve- or primed-enriched through previous differential gene expression analyses (Stirparo et al., 2018,

153 Messmer et al., 2019) after 5 days Dox induction (FIG.2C). We identified naïve-enriched factors that 154 were significantly upregulated in response to KLF17 induction: ARGFX (upregulated $\sim 65$-fold 155 average; $p \sim 0.03$ ), REX1/ZFP42 (upregulated $\sim 180$-fold average; $p \sim 0.02$ ) DPPA5 (upregulated $\sim 3.9$ 156 fold average; $p \sim 0.04$ ), DNMT3L (upregulated $\sim 300$-fold average; $p \sim 0.003$ ) and TFAP2C (upregulated $157 \sim 2$-fold average; $p \sim 0.03$ ). Of these genes, our recent scRNA-seq analysis revealed that under 158 equivalent conditions (H9 cells in mTeSR1 on matrigel) only REX1/ZFP42 is appreciably expressed in 159 primed hESCs (Wamaitha et al., 2020). Therefore, expression of KLF17 alone is sufficient not only to 160 upregulate a gene already active in conventional hESCs, but also to initiate expression of genes that 
161 are otherwise transcriptionally silent. On the other hand, expression of NANOG remained

162 transcriptionally unchanged, as did expression of the endogenous KLF17 gene (FIG.2C).

164 In order to understand the full extent of the gene expression changes following KLF17 overexpression, we performed mRNA-seq across a 5-day time course of induction. Dimensionality reduction by principal component analysis (PCA) separated the samples by treatment (uninduced (UI) or induced (+Dox)), as well as by timepoint (FIG.3A). Thus, ectopic expression of KLF17 in primed hESCs was sufficient to bring about considerable transcriptome-wide changes.

To determine the nature of the genes impacted upon by KLF17, we performed differential gene expression analysis between $\mathrm{UI}$ and +Dox samples at each timepoint. At day 5, we uncovered 1760 and 1315 up- and downregulated genes, respectively ( $\left.\mathrm{p}_{\mathrm{adj}}<0.05\right)$ (FIG.3B; Supp Table 1). Intriguingly, of the upregulated genes at day 5, $505(29 \%)$ have been previously identified as enriched in naïve hESCs (Stirparo et al., 2018, Messmer et al., 2019) and/or the human EPI itself (Blakeley et al., 2015), including 46 genes that are EPI-enriched but not differentially expressed between naïve and primed hESCs (e.g. LEFTY1, CALB1, ETV5, ETV4 and PFKP) (FIG.3C). In contrast, of the downregulated genes, $465(35 \%)$ were previously identified as enriched in primed versus naïve hESCs. The negatively regulated, hESC-associated genes included ITGA2 and ITGA4, MAPK10, IGFBPL1 and IDO1 (FIG.3D). This suggests that expression of KLF17 in hESCs cultured under primed culture conditions promotes a shift toward a more naïve pluripotent transcriptome.

182 It thus appears that KLF17 alone is sufficient to induce significant transcriptional change in primed hESCs over 5 days. To identify those genes most likely to be directly regulated by KLF17, we performed a time course correlation analysis. Using a cut-off for the correlation coefficient of 0.85 , we found 70 genes whose expression over time closely mimicked that of KLF17 itself (FIG.S2A; Supp Table 2). Of these genes, two-thirds (47) were classified as significantly enriched from day 1 $\left(p_{a d j}<0.05\right)$ and almost all (69) were classified as significantly enriched from day 2 onwards $\left(p_{\text {adj }}<0.05\right)$ (FIG.S2B-C), highlighting that these putative KLF17 targets were both rapidly and strongly upregulated following KLF17 induction. These genes included a number of components of the PI3K-

190 AKT-mTOR signalling pathway (PIK3AP1, TSC2, NOS3, FGF18, FGFR3, ITGB7 and LAMC2;

191 FIG.3E), which we recently showed to be active in both primed and naïve hESCs and a driver of primed hESC and human EPI proliferation (Wamaitha et al., 2020). Following KLF17 overexpression,

193 hESCs significantly upregulated ligands and receptors feeding in to PI3K and the downstream components NOS3 and TSC2 (FIG.S3A-G). Of note, all seven such genes are enriched in the human EPI compared to primed hESCs in mTeSR1 on matrigel (Wamaitha et al., 2020), as used in the current experiment. PI3K-AKT-mTOR signalling has also been previously suggested to support an alternative state of naïve pluripotency (Duggal et al., 2015). This suggests that KLF17 induction may modulate signalling through PI3K to a more naïve or EPI-like state. 
200 We investigated this possibility by western blotting, to determine the activation state of the PI3K

201 pathway in UI and +Dox hESCs (FIG.S3Q). We find that phosphorylation of AKT at Serine473 is

202 reduced following 5 days of KLF17 induction, indicating that the change in expression of PI3K-AKT

203 signalling components in response to KLF17 overexpression is sufficient to adjust the activity of this

204 signalling pathway. In particular, phosphorylation of AKT at Serine473 is usually mediated by the

205 activity of mTOR and stimulates full AKT activity (Alessi et al., 1996, Sarbassov et al., 2005), thereby

206 regulating functions including metabolism, growth and proliferation. A reduction in the levels of Ser473

207 phosphorylation following upregulation of genes associated with PI3K-AKT-mTOR signalling might

208 indicate negative feedback, acting to keep the KLF17-induced hESCs in a signalling steady state.

210 Other signalling factors were also highly correlated with KLF17, including JAKMIP2, FGFRL1 and

211 TNFRSF8 and the TGF $\beta$ signalling pathway components LEFTY2 and TGFB1/1. A number of cell

212 adhesion-related and cytoskeletal proteins were also included in this list: LAMC2, MUC4, COL5A1,

213 ITGB7 and MXRA5 (FIG.S3H-O). It is intriguing that the overexpression of KLF17 alone can influence

214 genes involved in such diverse processes, especially given the importance of changes in morphology

215 and signalling for the conversion of primed to naïve pluripotency. It therefore appears that KLF17 is

216 inducing some of these same resetting-associated changes without any external stimulation.

217

218 Of note is the strong expression correlation of KLF17 and the long non-coding RNA LINC-ROR

219 (correlation coefficient 0.921), which is upregulated 2 2.4-fold after 24hrs induction (FIG.S3P). LINC-

$220 R O R$ has been identified as a regulator of iPSC reprogramming (Loewer et al., 2010) and hESC self-

221 renewal (Wang et al., 2013). LINC-ROR expression is regulated by the core pluripotency transcription

222 factors OCT4, SOX2 and NANOG (Loewer et al., 2010) and in turn, acts as a sink for pluripotency

223 destabilising microRNAs (miRNAs) that target the mRNA of these core factors for degradation (Wang

224 et al., 2013). Thus, LINC-ROR appears to constitute an important feedback loop for pluripotency

225 maintenance in hESCs. The observed upregulation of LINC-ROR expression may therefore protect

226 the KLF17-induced hESCs from differentiation cues, as LINC-ROR overexpression has been shown

227 to have a protective effect (Wang et al., 2013).

229 Finally, we noted that of the 1711 genes downregulated following just 24 hours of Dox induction, there

230 is enrichment for terms related to WNT signalling. Activity of the WNT pathway has been suggested to

231 promote differentiation of hESCs, in both the primed and naïve pluripotent states (Davidson et al.,

232 2012, Singh et al., 2012, Bredenkamp et al., 2019b) and to be suppressed through cross-talk with the

233 PI3K-AKT signalling pathway (Singh et al., 2012). Therefore, downregulation of genes associated with

234 WNT signalling may suggest a further mechanism through which KLF17-overexpressing hESCs

235 would be refractory to differentiation cues. Interestingly, the inability to immediately undergo

236 differentiation in response to established protocols is a feature of naïve hESCs (Rostovskaya et al.,

237 2019).

238 
239 We confirmed the expression patterns of a number of DEGs by qRT-PCR, as well as validating their

240 upregulation at the protein level, including DNMT3L, VENTX, GP130/IL6ST and TFAP2C, the latter of

241 which is an essential regulator of naïve hESCs (Pastor et al., 2018) (FIG.3F, S4). Altogether this

242 supports our hypothesis that KLF17 acts to transcriptionally regulate genes associated with naïve

243 human pluripotency.

\section{KLF17 expression drives hESCs to naïve pluripotency alongside signalling modulation}

246 Given that KLF17 is sufficient to upregulate naïve pluripotency-associated factors under conventional primed hESC conditions, we hypothesised that KLF17 induction would be sufficient to reset primed hESCs to a naïve pluripotent state under the appropriate culture regime. The use of ectopic gene expression to drive resetting is common, with deployment of transgenes including OCT4, KLF4, SOX2, YAP, NANOG and/or KLF2 (Hanna et al., 2010, Theunissen et al., 2014, Takashima et al., 2014, Qin et al., 2016), with various media compositions. et al., 2017) and PXGL (Bredenkamp et al., 2019a, Bredenkamp et al., 2019b), revealed considerably stronger expression of the naïve markers DNMT3L and SUSD2, compared to cells treated equivalently in conventional mTeSR1 medium and untreated controls (FIG.4A, S5A). The upregulation of SUSD2 expression is particularly important to note, as it has been recently identified as a highly specific cell surface marker of naïve hESCs that can be used to enrich for naïve pluripotent cells from a heterogeneous population during resetting (Bredenkamp et al., 2019a). We therefore attempted to propagate the cells, by single cell passaging with MEFs, in both naïve and primed conditions after 5 days of KLF17 induction. Intriguingly, rounded and highly refractile colonies showing typical naïve hESC morphology began to appear only in cells treated with Dox in PXGL medium (FIG.4B, S5B). Conversely, the uninduced cells in PXGL had largely died. In all remaining conditions (mTeSR1 and tt2iL+Gö, +Dox and UI), the KLF17-inducible cells survived with either typical primed hESC morphology, that is, flattened, epithelial-like colonies, or evidence of differentiation (data not shown). This suggested that the ectopic expression of KLF17 is sufficient to reset conventional hESCs to a naïve-like pluripotent phenotype when supported by PXGL medium, with modulation of signalling via MEK/ERK (PD0325901), WNT (XAV939, Tankyrase inhibitor), PKC (Gö6983) and LIF/STAT3 (hLIF) (Guo et al., 2017). The unique ability of the PXGL formulation to support this primed-to-naïve transition may reflect its use in the early stages of chemical/epigenetic resetting (Guo et al., 2017), where it appears to perform better than tt2iL+Gö. Additionally, it suggests a particular importance of WNT signalling inhibition (by XAV939), which may relate to the observed downregulation of WNT signalling components in KLF17-induced primed hESCs. inducible naïve hESCs for a minimum of 5 passages, without requiring additional transgene activation beyond the initial 5-day period of Dox treatment (FIG.4B). We were able to confirm protein expression 
279 induction in primed culture conditions (FIG.4C). We therefore demonstrated that KLF17 is a potent

280 inducer of the naïve pluripotent state in hESCs.

\section{Designing a strategy for KLF17 mutation in hESCs}

283 The above investigations revealed that KLF17 is sufficient to induce the naïve pluripotent state in

284 hESCs. Next, we sought to determine whether KLF17 expression is required for resetting of primed

285 hESCs to naïve pluripotency. For this, we designed and optimised a protocol for CRISPR-Cas9mediated mutation of KLF17.

Using in silico tools, we designed five guide RNAs (gRNAs) against KLF17 (FIG.5A, S6A). We considered two strategies to achieve functional knockout of KLF17. First, by targeting the initiating methionine, we aimed to disrupt the entire coding sequence, leading to a complete loss of KLF17 expression. Alternatively, by targeting the functional domain, the DNA-binding ability could be directly disrupted, or a premature termination codon could be introduced, leading to production of a nonfunctional protein. We introduced Cas9 and each gRNA in turn into primed hESCs and harvested genomic DNA for deep sequencing of the KLF17 on-target locus by MiSeq analysis. Analysing the proportion of detected insertion and deletion (indel) mutations revealed that the introduction of Cas 9 and each of the gRNAs led to indels, with an average mutation efficiency of $\sim 60 \%$ (FIG.5B). However, gRNA KLF17(3_3) was clearly inferior and therefore we did not consider it any further.

In order to decide upon the optimal gRNA for generating KLF17 null mutant $\left(K L F 17^{-1}\right) \mathrm{hESC}$, we investigated the nature of the indels resulting from CRISPR-Cas9 targeting in each case. Firstly, it was clear that both KLF17(1_1) and KLF17(1_2) were biased towards the introduction of very small indel mutations, with the vast majority of indels less than $10 \mathrm{bp}$ in size (FIG.S6B). Targeting with either of the exon 1-targeted gRNAs would thus leave the possibility of KLF17 expression from an identified alternative initiating methionine, with the possibility of generating either an essentially wildtype protein or a dominant-negative KLF17 mutant, which could have unexpected consequences. We therefore focussed on the exon 3-targeting gRNAs, KLF17(3_1) and KLF17(3_2). The overall efficiency of these two gRNAs was very similar, but sequence analysis revealed a stronger propensity for the introduction of larger frameshift alleles by KLF17(3_1) (FIG.5C). By disrupting a larger stretch of sequence within the region encoding the KLF17 DNA-binding domain, longer frameshift indels would be expected to be more highly mutagenic. We therefore determined to generate $K L F 17^{-1-} \mathrm{hESC}$ lines using gRNA KLF17(3_1).

\section{KLF17-- $h E S C$ s are not impaired in their ability to adopt naïve pluripotency}

314 Following nucleofection and single-cell amplification of wild-type, primed hESCs, we generated 8

315 KLF17-targeted clones (FIG.S7A). Initial genotyping by short-range PCR and next-generation MiSeq

316 suggested a high proportion of homozygous editing (5 of 8 edited clones; FIG.S7A-B). However,

317 analysis of a $\sim 950$ bp region surrounding the on-target site revealed that these apparent homozygous

318 clones had actually undergone an unexpected, long-range editing event on one allele (FIG.S7A-B). 
319 This was apparent from the lack of amplification of both alleles, as determined by the presence of only

320 one variant-type at a highly polymorphic site in the human genome, while the remaining wild-type and

321 heterozygous clones confirmed that this variant is heterozygous in the parental cells (FIG.S7A-C).

322 The extent of the damage was only determined in one clone, \#9, where a 163 bp deletion could be

323 detected in the sequence. For the remaining 4 clones, the damage apparently completely prevented

324 amplification of the second allele. This highlights the importance of in-depth genotyping following

325 CRISPR-Cas9-mediated mutagenesis, as previously noted (Kosicki et al., 2018, Cullot et al., 2019,

326 Rayner et al., 2019, Przewrocka et al., 2020, Alanis-Lobato et al., 2020). We therefore sought to test

327 whether clones \#18 and \#19, compound mutants with two frameshifted alleles predicted to introduce

328 premature stop codons in the sequence encoding the third zinc fingers (FIG.S7D-F), were null for

329 KLF17 expression.

330

331 We subjected three wild-type control clones and clones \#18 and \#19 to chemical resetting (Guo et al., 332 2017) for eight days and observed robust coexpression of KLF17 and OCT4 in control cells, while the 333 compound mutants lacked detectable KLF17 protein (FIG.5D). To determine whether KLF17-/ hESCs 334 were able to adopt a naïve pluripotent phenotype, we repeated the chemical resetting and found that 335 both the wild-type controls and $K L F 17^{-1-} \mathrm{hESC}$ s could be propagated in $\mathrm{tt} 2 \mathrm{i} L+\mathrm{Gö}$ conditions for at least 33610 passages, maintaining typical naïve morphology (FIG.6A). To identify molecular differences arising 337 in KLF17-1- hESCs, we performed mRNA-seq at various timepoints throughout the chemical resetting

338 process. This confirmed lack of KLF17 expression in the compound mutant clones (FIG.6C). The lack 339 of appreciable KLF17 RNA expression (TPM $<5)$ suggests that the presence of premature termination 340 codons following the CRISPR-Cas9 target site induced nonsense-mediated decay of the mRNA 341 during translation (Nickless et al., 2017). Clones \#18 and \#19 are therefore bona fide KLF17-null 342 mutant hESCs. Despite this, PCA analysis of all samples revealed tight clustering of wild-type and

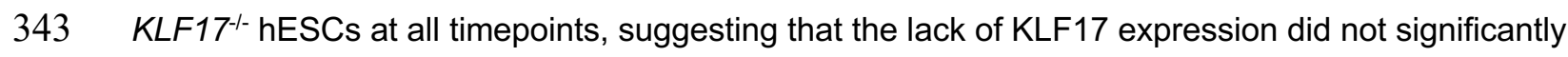

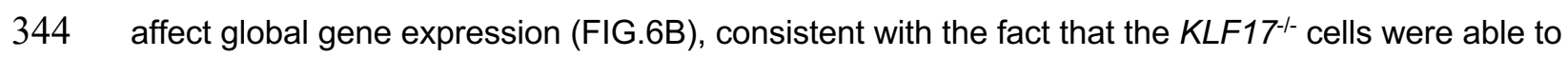
345 reset and survive long-term under naïve culture conditions. This may indicate that KLF17 expression 346 is not required for resetting under the given conditions, or there may be redundancy with other genes 347 that compensate for null mutations in KLF17.

349 Interestingly, analysis by DESeq2 identified the KLF17 paralogue $K L F 5$ as an early differentially 350 expressed gene, being significantly upregulated in $K L F 17^{-1-}$ versus wild-type naïve hESCs at day 2 of 351 the resetting process (FIG.6D), whereas KLF2 and KLF4 are expressed equivalently (FIG.6E-F). It is 352 therefore possible that during the early stage of resetting, where hESCs are undergoing global 353 epigenetic "opening" in response to histone deacetylase inhibition (Guo et al., 2017) and therefore 354 may be in a more phenotypically flexible state than usual, the brief upregulation of KLF5 is sufficient 355 to compensate for a function carried out by KLF17 in the wild-type state.

357 Despite this possible redundancy, further analysis revealed a considerable increase in the number of 358 DEGs between wild-type and mutant hESCs at naïve passage 5 (p5), by which point the naïve 
pluripotent phenotype is suggested to become more stable (Guo et al., 2017). At p5, 316 genes were

360 significantly upregulated and 311 genes were significantly downregulated $\left(p_{\text {adj }}<0.05\right)$ (FIG.6G; Supp

361 Table 3). Enrichment analysis identified significantly downregulated terms related to

362 "Glycolysis/Gluconeogenesis", "Fructose and mannose metabolism" and "Translation" among others,

363 while upregulated terms included "Signalling by WNT", "Proteasome" and "Protein processing in

364 endoplasmic reticulum". Some of the most important, rate limiting enzymes of glycolysis are included

365 in the list of significantly downregulated DEGs, including HK2, PFKL, ENO1 and ENO2, PGK1 and

366 PKM (FIG.S8A-F). If energy production through glycolytic metabolism is limited, proteasomal

367 degradation might be upregulated as a means to compensate, promoting metabolism of non-essential

368 proteins.

370 The enrichment terms for downregulated genes at $\mathrm{p} 5$ in KLF17-null naïve hESCs in fact overlap with

371 those of mRNAs identified as direct targets of the RNA-binding protein LIN28A (Peng et al., 2011),

372 which is itself significantly downregulated from p5 onwards (FIG.6H). LIN28A has been implicated in

373 pluripotency regulation in numerous studies (Heo et al., 2008, Kim et al., 2014, Viswanathan et al.,

374 2008, Yu et al., 2007), though a potential role specifically in naïve hESCs has not been explored.

375 Nevertheless, its significant and maintained downregulation may suggest that its expression depends

376 either directly or indirectly on KLF17 in tt2iL+Gö conditions.

378 Finally, upregulation of genes associated with WNT signalling in KLF17-- naïve hESCs is particularly

379 interesting, given the proposed role of WNT signalling in promoting hESC differentiation (Guo et al.,

380 2017). WNT ligands, receptors and scaffolding proteins are upregulated in the mutant cells (FIG.6I,

381 S8G-H), an effect that might only be observed at such a late timepoint due to the withdrawal of WNT

382 inhibition by XAV939. As stated earlier, KLF17 overexpression in primed hESCs also led to rapid

383 downregulation of a number of WNT components, such that it is an enriched term in the

384 downregulated DEGs at day 1 post-induction (Supp Table 4). This may suggest that WNT signalling is

385 either directly or indirectly regulated by KLF17 transcriptional activity and the continued inhibition of

386 WNT during the early stages of resetting may account for the ability of KLF17-null hESCs to adapt to

387 naïve culture.

389 Altogether this suggests that while KLF5 and KLF17 may display some redundant functions during the

390 establishment of naïve from primed pluripotency in hESCs, KLF17 $7^{-1-}$ naïve hESCs are not as

391 phenotypically stable as their wild-type counterparts, since KLF17 function appears to regulate

392 important metabolic and signalling pathways.

\section{Discussion}

395 In this study, we investigate the human EPI-enriched transcription factor KLF17. By IF analysis of 396 developing human blastocysts, we show that the protein dynamics of KLF17 are remarkably similar to 397 those of the known pluripotency factor SOX2. Both transcription factors display widespread

398 expression across all cells in the early blastocyst, with gradual restriction to the pluripotent EPI, 
marked by NANOG expression. Therefore, the expression pattern of KLF17 during pre-implantation human development is suggestive of a role in pluripotency regulation.

Indeed, we show that KLF17 is able to induce the expression of a naïve hESC-like transcriptome in primed hESCs and is furthermore sufficient to drive conventional primed to naïve hESC pluripotency. This implies that KLF17 is a powerful inducer of the human naïve pluripotent state in vitro and, given its in vivo expression, it is interesting to speculate that it may have a role in pluripotency establishment in the human embryo.

From transcriptome analysis of KLF17-overexpressing cells, we suggest that KLF17 may be involved in modulating the expression of components involved in various signalling pathways, primarily the PI3K-AKT and WNT pathways. Of note, the various signalling effectors that are differentially expressed following KLF17 induction are often the most highly correlated with KLF17 expression, as well as being some of the earliest DEGs. In contrast to this, known markers of naïve pluripotency like DNMT3L and SUSD2 are induced much later. This is suggestive of an indirect relationship between KLF17 induction and the expression of naïve pluripotency marker genes, which may well involve the direct action of KLF17 upon signalling effectors to promote naïve pluripotency and inhibit prodifferentiation cues. This is particularly interesting, given the roles of PI3K-AKT (Wamaitha et al., 2020) and WNT signalling in human pluripotency and differentiation (Singh et al., 2012, Bredenkamp et al., 2019b, Mathieu et al., 2019), and the apparent importance of WNT inhibition for recent methods of naïve pluripotency establishment (Zimmerlin et al., 2016, Guo et al., 2017, Bredenkamp et al., 2019b). In naïve hESCs, KLF17 might act to endogenously dampen WNT signalling by impinging upon the expression of components of the WNT pathway, thereby reinforcing the naïve state. primed $K L F 17^{-1-}$ hESCs are still able to adopt and maintain naïve pluripotency under the conditions investigated herein. This is surprising, given the rapid upregulation of KLF17 expression that has been reported during chemical resetting (Guo et al., 2017) and raises the possibility of genetic compensation. Indeed, KLF2, KLF4 and KLF5, which have all been implicated in pluripotency regulation and to have redundant functions with human KLF17 in mESCs (Yamane et al., 2018), are also rapidly upregulated in the early stages of resetting in both wild-type and $K L F 17^{-1-} \mathrm{hESCs}$. Furthermore, we observe that $K L F 5$ is transiently upregulated in KLF17-null cells versus wild-type controls at day 2 , and again at $\mathrm{p} 5$. While $K L F 5$ transcripts are more abundant in the TE of the human blastocyst (Blakeley et al., 2015), they are still appreciably expressed in both the EPI and PrE. This suggests that in vitro, and perhaps in vivo, KLF5 may fulfil overlapping functions with KLF17 in the establishment and/or maintenance of naïve pluripotency. Further work could address this question of compensation by performing dual knockout of both KLF17 and KLF5 in hESCs and investigating the cells' competency to undergo chemical resetting. However, the technology for genetic manipulation of

437 human embryos is still in its infancy and so it may unfortunately not be possible to test this hypothesis in vivo. 
440 Alternatively, it is feasible that no single factor acts to compensate for KLF17 knockout and instead, a combinatorial action of transcription factors with overlapping targets is able to maintain KLF17-null naïve hESCs. This situation would be reminiscent of that observed by manipulating the expression of "peripheral" pluripotency regulators in mouse embryos and mESCs, including KLF2 and KLF4, where individual peripheral factors are mostly dispensable, but together act to reinforce the stability of the pluripotent state mediated by the core factors, OCT4 and SOX2 (Nichols and Smith, 2012). For instance, knockdown of either KIf2, KIf4 or KIf5 in naïve mESCs does not appear detrimental (Jiang et al., 2008, Yamane et al., 2018) and Klf2- or Klf4-null mutant embryos are viable through preimplantation development (Wani et al., 1998, Ehlermann et al., 2003). Despite this, all three factors have validated roles in pluripotency (Parisi et al., 2008, Hall et al., 2009, Jiang et al., 2008).

While $K L F 17^{-1-}$ naïve hESCs did not overtly differ from wild-type counterparts, we did find interesting trends by differential gene expression at p5 of naïve culture, when WNT inhibition by XAV939 is withdrawn. We observe significant downregulation of metabolism and translation, concomitant with upregulation of protein degradation, in $K L F 17^{-1-}$ naïve hESCs. This is reminiscent of the transcriptome changes observed in primed hESCs treated with proteasome inhibition (Saez et al., 2018), which induces cells to enter a state of stress, reflected in their transcriptome. Thus, this overlap of the response of $K L F 17^{-1-}$ hESCs during naïve resetting and proteasome inhibition in primed cells may indicate an induction of the cellular stress response. In particular, the transcriptome changes are suggestive of metabolic stress at a key point during the stabilisation of the naïve pluripotent state, as we observe downregulation of key glycolytic enzymes. This may imply that without exogenous WNT inhibition to stabilise the naïve pluripotent state, and indeed with the observed upregulation of WNT signalling components, KLF17-null naïve hESCs become temporarily unstable.

This could also be reflected in the observed and consistent downregulation of LIN28A, as LIN28A has been directly implicated in the growth and survival of hESCs (Peng et al., 2011). By binding RNA, LIN28A regulates expression primarily at the post-transcriptional level. Thus, there may be further effects in $K L F 17^{-1-}$ naïve hESCs at the protein level, not reflected in the current transcriptome analysis. At p5, LIN28B is also significantly downregulated. Interestingly, LIN28 has been recently identified as a naïve-specific marker in porcine ESCs (Chen et al., 2020), at both the RNA and protein level, suggesting that its downregulation may be somewhat detrimental also in naïve hESCs. pluripotency in vitro. However, it is clear from our data that KLF17 expression is not necessary for establishing naïve hESCs, although our current work does not exclude the possibility that established naïve hESCs are sensitive to loss of KLF17, as recently suggested (Bayerl et al., 2020). We theorise that in a wild-type situation KLF17 may act as a peripheral pluripotency factor in human naïve pluripotency, acting alongside a core pluripotency network of OCT4 and SOX2 to maintain robustness 
downregulation of the differentiation-promoting WNT signalling pathway and its upregulation of factors like LINC-ROR, which are known to limit differentiation. out a more central role in pluripotency in the human embryo. To date, there have been no systematic comparisons of the outcomes of specific gene modulation in naïve hESCs versus the human pluripotent epiblast, but evidence suggests that they would not necessarily be conserved. For instance, Nanog-null naïve mESCs, while prone to differentiation, are still functionally pluripotent, with the capability for chimaera formation (Chambers et al., 2007). In contrast, a Nanog-null mouse embryo is unable to form a functional blastocyst or continue development from the peri-implantation stage onward (Mitsui et al., 2003, Chambers et al., 2003, Messerschmidt and Kemler, 2010, Frankenberg et al., 2011). This shows that the in vivo phenotype of genetic knockouts can be more severe than that observed in vitro. Furthermore, while knockdown of POU5F1 in hESCs causes the expected differentiation phenotype (Wang et al., 2012), even partial loss of OCT4 function in the human embryo had a much more drastic phenotype, with non-cell-autonomous effects across all three lineages at the blastocyst stage (Fogarty et al., 2017). For this reason, future investigation of the function of KLF17 in human in vivo pluripotency is an important next step.

\section{Materials and methods}

499 Human embryo thaw and culture conditions

500 Human embryos at various developmental stages that were surplus to family building desires were 501 donated to the Francis Crick Institute for use in research projects under the UK Human Fertilisation and Embryology Authority License number R0162. Slow-frozen blastocysts (day 5 and day 6) were thawed using the BlastThaw (Origio; 10542010A) kit using the manufacturer's instructions. Vitrified blastocysts (day 5 and day 6 ) were thawed using the vitrification thaw kit (Irvine Scientific; 90137-SO) following the manufacturer's instructions. Human embryos were cultured in pre-equilibriated Global Media (Life Global) supplemented with $5 \mathrm{mg} / \mathrm{ml}$ Life Global HSA (LifeGlobal; LGPS-605) and overlaid with mineral oil (Origio; ART-4008-5P and incubated in Embryoscope+ time lapse incubator (Vitrolife).

\section{Maintenance of standard hESC cultures}

510 Human embryonic stem cells (hESCs) were routinely cultured in mTeSR1 medium (Stem Cell

511 Technologies) on growth factor-reduced Matrigel-coated dishes (BD Biosciences) and passaged as

512 clumps at $\sim 1: 20$ ratio using ReLeSR (Stem Cell Technologies). Cells were maintained in humidified

513 incubators at $37^{\circ} \mathrm{C}, 5 \% \mathrm{CO}_{2}$.

516 All naïve hESCs were cultured under hypoxia $\left(5 \% \mathrm{O}_{2}, 5 \% \mathrm{CO}_{2}\right)$, according to recently published 517 protocols (Guo et al., 2017, Bredenkamp et al., 2019b) on mitotically-inactivated DR4 MEFs (prepared 518 in-house) plated at a density of $1 \times 10^{6}$ per well of a 6 -well plate $12-16 \mathrm{hrs}$ prior to hESC seeding. Naïve 
519 hESCs were passaged as single cells by 4 minutes treatment with Accutase (Thermo Fisher) at $37^{\circ} \mathrm{C}$,

520 at split ratios between 1:3 and 1:6, every 3 to 6 days. For culture in (t)t2iL+Gö, $10 \mu \mathrm{M}$ ROCK inhibitor

521 (Y-27632, Tocris Bioscience) was added overnight before and after passaging, to aid survival.

522 In-house generated, chemically reset, naïve $\mathrm{H} 9$ cells were maintained in $\mathrm{tt} 2 \mathrm{iL}+\mathrm{G}$, with $0.3 \mu \mathrm{M}$

523 CHIR99021 (Guo et al., 2017), and XAV supplementation until naïve passage 5.

\section{Generation and culture of overexpression hESC lines}

526 Doxycycline-inducible overexpression of HA-tagged proteins was achieved using the Lenti-X Tet-On

527 3G Inducible Expression System (Clontech) following the manufacturer's protocol, and as outlined

528 previously (Wamaitha et al., 2015). Lentiviral packaging was achieved using $7 \mu \mathrm{g}$ of transgene-

529 containing plasmid and the Lenti-X Packaging Single Shot reagents. Lentiviral supernatant was

530 harvested after 48hrs and concentrated by ultracentrifugation. To produce stably-transduced cells,

531 hESCs were plated under standard conditions and changed into fresh medium the following morning.

532 24hrs post-plating, $10 \mu \mathrm{l}$ concentrated virus was added to hESCs for transduction overnight ( 16hrs).

$533 \mathrm{hESCs}$ were dual selected with $150 \mu \mathrm{g} / \mathrm{ml} \mathrm{G} 418$ and $0.5 \mu \mathrm{g} / \mathrm{ml}$ puromycin 48hrs post-transduction.

534 For induction of transgene expression, doxycycline was added to mTeSR1 medium at $1 \mu \mathrm{g} / \mathrm{ml}$. For

535 the RNA-seq experiments, KLF17-inducible hESCs were plated as normal and induction initiated after

53624 hours by addition of $1 \mu \mathrm{g} / \mathrm{ml}$ Dox to the culture medium (mTeSR1). At $\sim 30$ hours, a day 0 (pre-

537 induction) control sample was collected, then both induced (+Dox) and uninduced (UI) samples were

538 collected at $24 \mathrm{hr}$ intervals from $48 \mathrm{hrs}$ (day 1 post-induction) until $144 \mathrm{hrs}$ (day 5 post-induction). RNA

539 was extracted from the samples and subjected to bulk RNA sequencing.

\section{KLF17-driven resetting of primed to naïve $h E S C s$}

542 H9 KLF17-HA inducible hESCs were pre-treated overnight with $10 \mu \mathrm{M} \mathrm{ROCKi}$, then harvested from

543 standard culture (mTeSR1 on matrigel) by 5 minutes incubation at $37^{\circ} \mathrm{C}$ with accutase, resuspended

544 in culture medium supplemented with $10 \mu \mathrm{M}$ ROCKi and counted. $2 \times 10^{5} \mathrm{hESC}$ s were plated per 6-

545 well pre-coated in DR4 MEFs and the cells placed at hypoxia $\left(5 \% \mathrm{O}_{2}, 5 \% \mathrm{CO}_{2}\right)$ for $\sim 24 \mathrm{hrs}$. The

546 following day (day 0), medium was changed to PXGL supplemented with $1 \mu \mathrm{g} / \mathrm{ml}$ Dox. From day 2 ,

547 medium was replenished each day with PXGL freshly supplemented with $1 \mu \mathrm{g} / \mathrm{ml}$ Dox. On day 5 , cells

548 were passaged by $4 \mathrm{~min}$ incubation in accutase and plated in PXGL with $10 \mu \mathrm{M}$ ROCKi at a split ratio

549 between $1: 5$ and 1:20, dependent upon density. Within $24 \mathrm{hrs}$, the cells adopted a domed morphology

550 with highly-refractile colony edges. Cells were passaged again on day 7 or 8 and could subsequently

551 be maintained similarly to chemically-reset cells (Guo et al., 2017), with passaging every 3-4 days at

552 split ratios of between 1:3 and 1:6.

553

\section{Design of gRNAs}

555 Guide RNAs (gRNAs) were designed in a non-biased manner against the whole cDNA sequence 556 using a standard design tool (Hsu et al., 2013). For initial screening, gRNAs were selected on the 557 following criteria: (i) in silico score is $\geq 60$; (ii) identified off-target sites have $\geq 3$ mismatches; (iii) there 
are no (or very low frequency, $\leq 0.1 \%$ ) single nucleotide polymorphisms (SNPs) occurring in the target sequence; (iv) the gRNA target site falls across an annotated DNA-binding domain.

\section{Transient nucleofection of $h E S C s$}

562 For cell line testing of CRISPR-Cas9 efficiency, gRNAs were individually cloned into pSpCas9(BB)563 2A-Puro (PX459) V2.0 (Addgene plasmid \#62988) (Ran et al., 2013), using the Bbsl restriction sites.

564 Nucleofection was carried out on an Amaxa 4D-Nucleofector (Lonza) with $4 \mu \mathrm{g}$ plasmid. 24 hours prior to nucleofection, H9 hESCs were treated with $10 \mu \mathrm{M} \mathrm{Y-27632} \mathrm{(Tocris} \mathrm{Bioscience).} \mathrm{hESCs} \mathrm{were}$ harvested as single cells by Accutase treatment $\left(5 \mathrm{~min}, 37^{\circ} \mathrm{C}\right)$ and counted with an automatic cell counter (Nucleocounter NC-200, ChemoMetec). For each gRNA, $2 \times 10^{6}$ cells were resuspended in $100 \mu \mathrm{l} \mathrm{P3}$ Primary Cell 4D-Nucleofector $X$ Solution and transferred to nucleocuvettes with $4 \mu \mathrm{g}$ plasmid. Nucleofection was performed with the pre-set H9 hESC programme (CB-150), then cells resuspended in antibiotic-free mTeSR1 medium supplemented with $10 \mu \mathrm{M}$ Y-27632 and plated across half of a 6-well plate coated with DR4 MEFs to aid attachment and survival. After 24hrs, medium was changed to mTeSR 1 supplemented with $0.5 \mu \mathrm{g} / \mathrm{ml}$ puromycin for $48 \mathrm{hrs}$. Cells were allowed to recover for 8 days prior to harvesting for DNA extraction and assessment of CRISPR-Cas9 editing efficiency by MiSeq analysis. On-target editing was assessed by next-generation sequencing on the MiSeq platform (Illumina), and editing efficiency determined by analysing the FastQ files using both the Cas-Analyzer tool from CRISPR RGEN Tools (Park et al., 2017) and the CrispRVariants package in $\mathrm{R}$ (Lindsay et al., 2016).

\section{Generation of clonal knockout hESCs}

580 H9 hESCs were first nucleofected with $4 \mu \mathrm{g}$ pSpCas9(BB)-2A-Puro (PX459) V2.0 containing the gRNA KLF17(3_1) as described above. Following 48hrs treatment with $0.5 \mu \mathrm{g} / \mathrm{ml}$ puromycin, cells were allowed to recover on DR4 MEFs for $\sim 10$ days, then manually passaged as single cells following treatment with Accutase $\left(5\right.$ minutes, $\left.37^{\circ} \mathrm{C}\right)$ or Accumax $\left(10\right.$ minutes, $37^{\circ} \mathrm{C}$; Sigma Aldrich) at clonal density into Matrigel-coated 24-well tissue culture plates (Corning). Cells were sub-cloned once more by manual picking and single-cell dissociation into 12-well plates, then 24 clones passaged in duplicate and assessed for KLF17 mutation by on-target Sanger sequencing and MiSeq analysis.

\section{Immunofluorescence analysis}

Cultured cells were fixed with $4 \%$ paraformaldehyde (PFA) in PBS for $1 \mathrm{hr}$ at $4^{\circ} \mathrm{C}$, then permeabilised in PBS containing $0.5 \%$ Tween-20 (PBS-T(0.5\%)) for 20 minutes at room temperature. Blocking was carried out for $1 \mathrm{hr}$ at RT in PBS-T(0.1\%) with $10 \%$ donkey serum. Primary antibodies were diluted as listed in TABLE 1 in blocking solution, and incubated overnight at $4^{\circ} \mathrm{C}$. Cells were washed several times in PBS-T(0.1\%), then incubated in secondary antibodies in blocking solution for $1 \mathrm{hr}$ at RT. Following repeated washing, cells were treated with DAPI-Vectashield mounting medium (Vector Labs) at 1 in 30 in PBS-T(0.1\%), prior to imaging on an Olympus IX73 (Olympus Corporation). 
was performed for $1 \mathrm{hr}$ at RT in PBS-Tx(0.2\%) containing $10 \%$ donkey serum and $3 \%$ bovine serum albumin (BSA). Primary antibodies were diluted as listed in TABLE 1 in blocking solution, and incubated overnight at $4^{\circ} \mathrm{C}$. Embryos were washed several times, then incubated in secondary antibodies in blocking solution for $1 \mathrm{hr}$ at RT. Following repeated washing, embryos were transferred into DAPI-Vectashield mounting medium (Vector Labs) at 1 in 30 in PBS-T(0.1\%) on coverslip dishes (MatTek), and imaged on a Leica SP8 inverted confocal microscope (Leica Microsystems).

RNA isolation from $h E S C s$ and $q R T-P C R$

606 RNA was isolated using TRI reagent (Sigma) and DNase l-treated (Ambion). cDNA was synthesized using a Maxima first strand cDNA synthesis kit (Fermentas). qRT-PCR was performed using SensiMix SYBR low-ROX kit (Bioline) on a QuantStudio5 machine (Thermo Fisher). Primers pairs used are listed in TABLE 2. Each sample was run in triplicate. Gene expression was normalized using GAPDH as the housekeeping gene, and the results analysed using the $\Delta \Delta \mathrm{Ct}$ method.

\section{RNA sequencing}

613 For RNA-seq, RNA was isolated and DNase-treated as above, and libraries were prepared using the 614 polyA KAPA mRNA HyperPrep Kit (Roche). Quality of submitted RNA samples and the resulting 615 cDNA libraries was determined by ScreenTape Assay on a 4200 TapeStation (Agilent). Prepared 616 libraries were submitted for single-ended 75 bp sequencing on an Illumina HiSeq 4000 (Illumina).

\section{Genomic DNA extraction}

619 Total genomic DNA was extracted from hESCs using the DNeasy Blood and Tissue Kit (Qiagen)

620 following manufacturer's instructions. The concentration and purity of extracted DNA was measured using a nanodrop (DeNovix).

\section{Protein extraction and quantification}

624 hESCs were harvested for protein extraction by addition of CelLytic M lysis buffer (Merck), freshly 625 supplemented with protease inhibitors (PIC, cOmplete, EDTA-free protease inhibitor cocktail, Roche) 626 and phosphatase inhibitors (PhIC, phosSTOP phosphatase inhibitor, Roche), directly onto plated 627 cells. Cells were scraped, then incubated in lysis buffer for $15 \mathrm{~min}$ at $4^{\circ} \mathrm{C}$. The lysate was collected 628 and clarified by centrifugation at $20,000 \times$ g for $15 \mathrm{~min}$ at $4^{\circ} \mathrm{C}$. Protein concentration in the lysates was 629 determined using the BCA assay, then proteins denatured by addition of $4 x$ Laemmli sample buffer 630 (Thermo Fisher) and heating at $90^{\circ} \mathrm{C}$ for 5 minutes.

\section{Protein detection by western blotting}

633 Denatured proteins were thawed at $65^{\circ} \mathrm{C}$ for 5 minutes and vortexed to ensure homogeneity. $20 \mu \mathrm{g}$

634 protein per lane was loaded onto 10\% Mini-PROTEAN TGX Stain-free protein gels (BIORAD),

635 alongside $5 \mu$ PageRuler Prestained Protein Ladder (Thermo Scientific), and electrophoresed at 100-

$636200 \mathrm{~V}$ for one to two hours in a Mini-PROTEAN Tetra Vertical Electrophoresis Cell (BIORAD).

637 Proteins were transferred onto PVDF membranes (TransBlot Turbo Mini PVDF Transfer Packs, 
638 BIORAD) using a Trans-Blot Turbo Transfer System (BIORAD). PVDF membranes were blocked for

639 one hour in TBS-T(0.1\%) containing $5 \%$ non-fat milk and incubated with primary antibodies diluted in

640 either $5 \%$ milk or $5 \%$ BSA in TBST-T $(0.1 \%)$ as shown in TABLE 3 overnight at $4{ }^{\circ} \mathrm{C}$. Following washes

641 with TBS-T(0.1\%), membranes were incubated with secondary antibodies in $5 \%$ milk for one hour at

642 room temperature. Proteins of interest were visualised using the SuperSignal West Dura Extended

643 Duration Substrate or SuperSignal West Femto Maximum Sensitivity Substrate (Thermo Scientific)

644 and imaged on an Amersham Imager 600RGB (GE Healthcare).

645

646 Bulk RNA-sequencing analysis

647 The 'Trim Galore!' utility version 0.4.2 was used to remove sequencing adaptors and to quality trim

648 individual reads with the q-parameter set to 20

649 (https://www.bioinformatics.babraham.ac.uk/projects/trim galore/ (retrieved 03-05-2017)). Then

650 sequencing reads were aligned to the human genome and transcriptome (Ensembl GRCh38 release-

651 89) using RSEM version 1.3.0 (Li and Dewey, 2011) in conjunction with the STAR aligner version

652 2.5.2 (Dobin et al., 2013). Sequencing quality of individual samples was assessed using FASTQC

653 version 0.11 .5 (https://www.bioinformatics.babraham.ac.uk/projects/fastacl (retrieved 03-05-2017))

654 and RNA-SeQC version 1.1.8 (DeLuca et al., 2012). Differential gene expression was determined

655 using the R-bioconductor package DESeq2 version 1.24.0 (Love et al., 2014). Within the DESeq2

656 package, adjusted $p$ values for log-fold changes were calculated using the Benjamini-Hochberg

657 method and the betaPrior parameter was set to "TRUE". For the KLF17-1- hESCs in naïve conditions,

658 each timepoint was normalised individually, to account for the significant cell-state changes occurring

659 across the long time course of the experiment ( 60 days).

660

661

\section{Acknowledgements}

663 We thank the donors of human embryos whose contributions enable this research. Further, we thank

664 all members of the Niakan lab for their technical assistance and for help and comments on the paper,

665 and James Briscoe, Robin Lovell-Badge and Jonathan Chubb for advice throughout the project. We

666 are grateful to the Francis Crick Institute's Science Technology Platforms: Robert Goldstone and Deb

667 Jackson from the Advanced Sequencing Facility; Advanced Light Microscopy; and the Genomics

668 Equipment Park.

669

\section{$670 \quad$ Competing Interests}

671 No competing interests declared.

\section{Author Contributions}

674 R.A.L. performed the experiments with assistance from A.M. S.B. performed major bioinformatics

675 analysis with assistance from R.A.L. K.K.N. and R.A.L. conceived the study and analysed data. R.A.L.

676 wrote the manuscript with feedback from all authors. 


\section{$678 \quad$ Funding}

679 This research was funded in whole, or in part, by the Wellcome Trust FC001120. For the purpose of

680 Open Access, the author has applied a CC BY public copyright licence to any Author Accepted

681 Manuscript version arising from this submission. The Francis Crick Institute receives its core funding

682 from Cancer Research UK (FC001120, FC001193 and FC001070), the UK Medical Research Council

683 (FC001120, FC001193 and FC001070), and the Wellcome Trust (FC001120, FC001193 and

684 FC001070).

685

686

687

688

689

690

691

692

693

694

695

696

697

698

699

700

701

702

703

704

705

706

707

708

709

710

711

712

713

714

715

716 


\begin{tabular}{|c|c|c|c|c|}
\hline Target & Species & Dilution & Supplier & $\begin{array}{l}\text { Catalogue } \\
\text { Number }\end{array}$ \\
\hline Anti-DNMT3L & Mouse & 1 in 500 & Abcam & ab93613 \\
\hline Anti-GP130 & Rabbit & 1 in 250 & Thermo Fisher & PA5-80735 \\
\hline Anti-HA (3F10) & Rat & 1 in 500 & $\begin{array}{l}\text { Sigma Aldrich } \\
\text { (Roche) }\end{array}$ & 11867423001 \\
\hline Anti-KLF17 & Rabbit & $\begin{array}{l}1 \text { in } 500 \text { (hESCs) } \\
1 \text { in } 200 \text { (embryo) }\end{array}$ & Atlas Antibodies & HPA024629 \\
\hline Anti-NANOG & Goat & 1 in 200 & R\&D Systems & AF1997 \\
\hline Anti-OCT4 & Mouse & 1 in 100 & $\begin{array}{c}\text { Santa Cruz } \\
\text { Biotechnology }\end{array}$ & SC-5279 \\
\hline Anti-SOX2 & Rat & 1 in 100 & Invitrogen & $14-9811-82$ \\
\hline Anti-SUSD2 & Mouse & 1 in 250 & Biolegend & 327401 \\
\hline Anti-TFAP2C & Goat & 1 in 200 & R\&D Systems & AF5059 \\
\hline Anti-VENTX & Rabbit & 1 in 500 & $\begin{array}{l}\text { Cambridge } \\
\text { Bioscience }\end{array}$ & HPA050955 \\
\hline $\begin{array}{c}\text { Alexa Fluor } \\
\text { anti-mouse IgG }\end{array}$ & Donkey & 1 in 300 & Invitrogen & $\begin{array}{l}\text { A21202 }(488 \mathrm{~nm}) \\
\text { A21203 }(594 \mathrm{~nm}) \\
\text { A31571 }(647 \mathrm{~nm})\end{array}$ \\
\hline $\begin{array}{c}\text { Alexa Fluor } \\
\text { anti-rabbit IgG }\end{array}$ & Donkey & 1 in 300 & Invitrogen & $\begin{array}{l}\text { A21206 }(488 \mathrm{~nm}) \\
\text { A21207 }(594 \mathrm{~nm}) \\
\text { A31573 }(647 \mathrm{~nm})\end{array}$ \\
\hline $\begin{array}{c}\text { Alexa Fluor } \\
\text { anti-goat IgG }\end{array}$ & Donkey & 1 in 300 & Invitrogen & $\begin{array}{l}\text { A11055 }(488 \mathrm{~nm}) \\
\text { A11058 }(594 \mathrm{~nm}) \\
\text { A21447 }(647 \mathrm{~nm})\end{array}$ \\
\hline $\begin{array}{l}\text { Alexa Fluor } \\
\text { anti-rat IgG }\end{array}$ & Donkey & 1 in 300 & Invitrogen & $\begin{array}{l}\text { A21208 }(488 \mathrm{~nm}) \\
\text { A21209 }(594 \mathrm{~nm})\end{array}$ \\
\hline
\end{tabular}




\begin{tabular}{|c|c|c|}
\hline Target & Forward primer sequence & Reverse primer sequence \\
\hline ARGFX & CCAGTTTCACTCTGTTATCCAAG & CGTTCTTTATGCCTTCTCCG \\
\hline DNMT3L & GGACCCTTCGATCTTGTGTA & ACCAGATTGTCCACGAACAT \\
\hline DPPA5 & GTGGTTTACGGCTCCTATTT & TCATCCAAGGGCCTAGTT \\
\hline GAPDH & GATGACATCAAGAAGGTGGTG & GTCTACATGGCAACTGTGAGG \\
\hline KLF17 & ACCCAGTCTTCATGTACGGC & GCACTCCAGAGCTTCCAGAA \\
\hline KLF17_HA & ACACCAGAAGACTCATCGGC & ACATCGTATGGGTAAGGACCAG \\
\hline NANOG & CATGAGTGTGGATCCAGCTTG & CCTGAATAAGCAGATCCATGG \\
\hline REX1/ZFP42 & GGAATGTGGGAAAGCGTTCGT & CCGTGTGGATGCGCACGT \\
\hline TFCP2L1 & AGCACATCCACCGAGTCTAC & TGAGGACAAAACAGGATTCATCT \\
\hline VENTX & CAGCTCTCAGAGGTCCAGATA & AGACGTTGAGTAGAAAGCTGG \\
\hline
\end{tabular}


802

803

804

805

806

807

808

809

810

811

812

813

814

\begin{tabular}{|c|c|c|c|c|}
\hline Target & Species & Dilution & Supplier & $\begin{array}{l}\text { Catalogue } \\
\text { Number }\end{array}$ \\
\hline Anti-alpha tubulin & Mouse & 1 in 1000 & Sigma Aldrich & T9026 \\
\hline Anti-pan AKT & Rabbit & 1 in 1000 & $\begin{array}{l}\text { Cell Signaling } \\
\text { Technologies }\end{array}$ & 9272 \\
\hline $\begin{array}{c}\text { Anti-phospho AKT } \\
\text { (Ser473) }\end{array}$ & Rabbit & 1 in 1000 & $\begin{array}{l}\text { Cell Signaling } \\
\text { Technologies }\end{array}$ & 9271 \\
\hline Anti-KLF17 & Rabbit & 1 in 500 & Atlas Antibodies & HPA024629 \\
\hline Anti-pan S6 & Mouse & 1 in 1000 & $\begin{array}{l}\text { Cell Signaling } \\
\text { Technologies }\end{array}$ & (54D2) \#2317 \\
\hline Anti-phospho S6 & Rabbit & 1 in 1000 & $\begin{array}{l}\text { Cell Signaling } \\
\text { Technologies }\end{array}$ & \#2211 \\
\hline $\begin{array}{c}\text { Anti-mouse lgG }(\mathrm{H}+\mathrm{L}) \\
\text { HRP-conjugated }\end{array}$ & Goat & 1 in 20000 & $\begin{array}{l}\text { Cell Signaling } \\
\text { Technologies }\end{array}$ & 7076 \\
\hline $\begin{array}{l}\text { Anti-rabbit IgG }(\mathrm{H}+\mathrm{L}), \\
\text { HRP-conjugated }\end{array}$ & Goat & 1 in 20000 & $\begin{array}{l}\text { Cell Signaling } \\
\text { Technologies }\end{array}$ & 7074 \\
\hline $\begin{array}{l}\text { Anti-goat IgG }(\mathrm{H}+\mathrm{L}) \text {, } \\
\text { HRP-conjugated }\end{array}$ & Donkey & 1 in 20000 & $\begin{array}{c}\text { Santa Cruz } \\
\text { Biotechnology }\end{array}$ & SC-2020 \\
\hline $\begin{array}{c}\text { Anti-rat IgG }(\mathrm{H}+\mathrm{L}), \mathrm{HRP}- \\
\text { conjuqated }\end{array}$ & Goat & 1 in 20000 & $\begin{array}{l}\text { Cell Signaling } \\
\text { Technologies }\end{array}$ & 7077 \\
\hline
\end{tabular}




\section{References}

ALANIS-LOBATO, G., ZOHREN, J., MCCARTHY, A., FOGARTY, N. M. E., KUBIKOVA, N., HARDMAN, E., GRECO, M., WELLS, D., TURNER, J. M. A. \& NIAKAN, K. K. 2020. Frequent loss-of-heterozygosity in CRISPR-Cas9-edited early human embryos. bioRxiv, 2020.06.05.135913.

ALESSI, D. R., ANDJELKOVIC, M., CAUDWELL, B., CRON, P., MORRICE, N., COHEN, P. \& HEMMINGS, B. A. 1996. Mechanism of activation of protein kinase B by insulin and IGF-1. EMBO J, 15, 6541-51.

ALI, A., BHATTI, M. Z., SHAH, A. S., DUONG, H. Q., ALKREATHY, H. M., MOHAMMAD, S. F., KHAN, R. A. \& AHMAD, A. 2015a. Tumor-suppressive p53 Signaling Empowers Metastatic Inhibitor KLF17-dependent Transcription to Overcome Tumorigenesis in Non-small Cell Lung Cancer. J Biol Chem, 290, 21336-51.

ALI, A., ZHANG, P., LIANGFANG, Y., WENSHE, S., WANG, H., LIN, X., DAI, Y., FENG, X. H., MOSES, R., WANG, D., LI, X. \& XIAO, J. 2015b. KLF17 empowers TGF-beta/Smad signaling by targeting Smad3-dependent pathway to suppress tumor growth and metastasis during cancer progression. Cell Death Dis, 6, e1681.

BAYERL, J., AYYASH, M., SHANI, T., MANOR, Y., GAFNI, O., KALMA, Y., AGUILERA-CASTREJON, KRUPALNIK, V., OLDAK, B., LIVNAT, N., TARAZI, S., TAWIL, S., LASMAN, L., HANNA, S., NOVERSHTERN, N., BEN-YOSEF, D., VIUKOV, S. \& HANNA, J. H. 2020. Tripartite Inhibition of SRC-WNT-PKC Signalling Consolidates Human Naïve Pluripotency. bioRxiv, 2020.05.23.112433.

BERNARDO, A. S., JOUNEAU, A., MARKS, H., KENSCHE, P., KOBOLAK, J., FREUDE, K., HALL, V., FEHER, A., POLGAR, Z., SARTORI, C., BOCK, I., LOUET, C., FAIAL, T., KERSTENS, H. H. HYTTEL, P., STUNNENBERG, H. G., HUYNEN, M., PEDERSEN, R. A. \& DINNYES, A. 2018. 
850

BOROVIAK, T., LOOS, R., LOMBARD, P., OKAHARA, J., BEHR, R., SASAKI, E., NICHOLS, J., SMITH, A. \& BERTONE, P. 2015. Lineage-Specific Profiling Delineates the Emergence and Progression of Naive Pluripotency in Mammalian Embryogenesis. Dev Cell, 35, 366-82.

BREDENKAMP, N., STIRPARO, G. G., NICHOLS, J., SMITH, A. \& GUO, G. 2019a. The CellSurface Marker Sushi Containing Domain 2 Facilitates Establishment of Human Naive Pluripotent Stem Cells. Stem Cell Reports.

BREDENKAMP, N., YANG, J., CLARKE, J., STIRPARO, G. G., VON MEYENN, F., DIETMANN, S., BAKER, D., DRUMMOND, R., REN, Y., LI, D., WU, C., ROSTOVSKAYA, M., EMINLIMEISSNER, S., SMITH, A. \& GUO, G. 2019b. Wnt Inhibition Facilitates RNA-Mediated Reprogramming of Human Somatic Cells to Naive Pluripotency. Stem Cell Reports, $13,1083-1098$.

CHAMBERS, I., COLBY, D., ROBERTSON, M., NICHOLS, J., LEE, S., TWEEDIE, S. \& SMITH, A. 2003. Functional expression cloning of Nanog, a pluripotency sustaining factor in embryonic stem cells. Cell, 113, 643-55.

CHAMBERS, I., SILVA, J., COLBY, D., NICHOLS, J., NIJMEIJER, B., ROBERTSON, M., VRANA, J., JONES, K., GROTEWOLD, L. \& SMITH, A. 2007. Nanog safeguards pluripotency and mediates germline development. Nature, 450, 1230-4.

CHEN, Q., ZHANG, H., JIANG, H., ZHANG, M., WANG, J., ZHAO, L., WANG, C., LIU, M. \& LI, R. 2020. Conversion between porcine naive-like and primed ESCS and specific pluripotency marker identification. In Vitro Cell Dev Biol Anim, 56, 412-423.

CULLOT, G., BOUTIN, J., TOUTAIN, J., PRAT, F., PENNAMEN, P., ROORYCK, C., TEICHMANN, M., ROUSSEAU, E., LAMRISSI-GARCIA, I., GUYONNET-DUPERAT, V., BIBEYRAN, A., LALANNE, M., PROUZET-MAULÉON, V., TURCQ, B., GED, C., BLOUIN, J.-M., RICHARD, E., DABERNAT, S., MOREAU-GAUDRY, F. \& BEDEL, A. 2019. CRISPR-Cas9 genome editing induces megabase-scale chromosomal truncations. Nature Communications, 10.

DAVIDSON, K. C., ADAMS, A. M., GOODSON, J. M., MCDONALD, C. E., POTTER, J. C., BERNDT, J. D., BIECHELE, T. L., TAYLOR, R. J. \& MOON, R. T. 2012. Wnt/beta-catenin signaling promotes differentiation, not self-renewal, of human embryonic stem cells and is repressed by Oct4. Proc Natl Acad Sci U S A, 109, 4485-90. 
881

882

883

884

885

886

887

888

889

890

891

892

893

894

895

896

897

898

899

900

901

902

903

904

905

906

907

908

909

910

911

912

DELUCA, D. S., LEVIN, J. Z., SIVACHENKO, A., FENNELL, T., NAZAIRE, M. D., WILLIAMS, C., REICH, M., WINCKLER, W. \& GETZ, G. 2012. RNA-SeQC: RNA-seq metrics for quality control and process optimization. Bioinformatics, 28, 1530-2.

DOBIN, A., DAVIS, C. A., SCHLESINGER, F., DRENKOW, J., ZALESKI, C., JHA, S., BATUT, P., CHAISSON, M. \& GINGERAS, T. R. 2013. STAR: ultrafast universal RNA-seq aligner. Bioinformatics, 29, 15-21.

DUGGAL, G., WARRIER, S., GHIMIRE, S., BROEKAERT, D., VAN DER JEUGHT, M., LIERMAN, S., DEROO, T., PEELMAN, L., VAN SOOM, A., CORNELISSEN, R., MENTEN, B., MESTDAGH, P., VANDESOMPELE, J., ROOST, M., SLIEKER, R. C., HEIJMANS, B. T., DEFORCE, D., DE SUTTER, P., DE SOUSA LOPES, S. C. \& HEINDRYCKX, B. 2015. Alternative Routes to Induce Naive Pluripotency in Human Embryonic Stem Cells. Stem Cells, 33, 2686-98.

EHLERMANN, J., PFISTERER, P. \& SCHORLE, H. 2003. Dynamic expression of Kruppel-like factor 4 (Klf4), a target of transcription factor AP-2alpha during murine midembryogenesis. Anat Rec A Discov Mol Cell Evol Biol, 273, 677-80.

FOGARTY, N. M. E., MCCARTHY, A., SNIJDERS, K. E., POWELL, B. E., KUBIKOVA, N., BLAKELEY, P., LEA, R., ELDER, K., WAMAITHA, S. E., KIM, D., MACIULYTE, V., KLEINJUNG, J., KIM, J. S., WELLS, D., VALLIER, L., BERTERO, A., TURNER, J. M. A. \& NIAKAN, K. K. 2017. Genome editing reveals a role for OCT4 in human embryogenesis. Nature, 550, 6773.

FRANKENBERG, S., GERBE, F., BESSONNARD, S., BELVILLE, C., POUCHIN, P., BARDOT, O. \& CHAZAUD, C. 2011. Primitive endoderm differentiates via a three-step mechanism involving Nanog and RTK signaling. Dev Cell, 21, 1005-13.

GAO, L., WU, K., LIU, Z., YAO, X., YUAN, S., TAO, W., YI, L., YU, G., HOU, Z., FAN, D., TIAN, Y., LIU, J., CHEN, Z. J. \& LIU, J. 2018. Chromatin Accessibility Landscape in Human Early Embryos and Its Association with Evolution. Cell, 173, 248-259 e15.

GERRI, C., MCCARTHY, A., ALANIS-LOBATO, G., DEMTSCHENKO, A., BRUNEAU, A., LOUBERSAC, S., FOGARTY, N. M. E., HAMPSHIRE, D., ELDER, K., SNELL, P., CHRISTIE, L., DAVID, L., VAN DE VELDE, H., FOULADI-NASHTA, A. A. \& NIAKAN, K. K. 2020. Initiation of a conserved trophectoderm program in human, cow and mouse embryos. Nature.

GUMIREDDY, K., LI, A., GIMOTTY, P. A., KLEIN-SZANTO, A. J., SHOWE, L. C., KATSAROS, D., COUKOS, G., ZHANG, L. \& HUANG, Q. 2009. KLF17 is a negative regulator of 
epithelial-mesenchymal transition and metastasis in breast cancer. Nat Cell Biol, 11, 1297-304.

GUO, G., VON MEYENN, F., ROSTOVSKAYA, M., CLARKE, J., DIETMANN, S., BAKER, D., SAHAKYAN, A., MYERS, S., BERTONE, P., REIK, W., PLATH, K. \& SMITH, A. 2017. Epigenetic resetting of human pluripotency. Development, 144, 2748-2763.

GUO, G., VON MEYENN, F., SANTOS, F., CHEN, Y., REIK, W., BERTONE, P., SMITH, A. \& NICHOLS, J. 2016. Naive Pluripotent Stem Cells Derived Directly from Isolated Cells of the Human Inner Cell Mass. Stem Cell Reports, 6, 437-46.

HALL, J., GUO, G., WRAY, J., EYRES, I., NICHOLS, J., GROTEWOLD, L., MORFOPOULOU, S., HUMPHREYS, P., MANSFIELD, W., WALKER, R., TOMLINSON, S. \& SMITH, A. 2009. Oct4 and LIF/Stat3 Additively Induce Krüppel Factors to Sustain Embryonic Stem Cell Self-Renewal. Cell Stem Cell, 5, 597-609.

HEO, I., JOO, C., CHO, J., HA, M., HAN, J. \& KIM, V. N. 2008. Lin28 mediates the terminal uridylation of let-7 precursor MicroRNA. Mol Cell, 32, 276-84.

HSU, P. D., SCOTT, D. A., WEINSTEIN, J. A., RAN, F. A., KONERMANN, S., AGARWALA, V., LI, Y., FINE, E. J., WU, X., SHALEM, O., CRADICK, T. J., MARRAFFINI, L. A., BAO, G. \& ZHANG, F. 2013. DNA targeting specificity of RNA-guided Cas9 nucleases. Nat Biotechnol, 31, 827-32. NG, H. H. 2008. A core KIf circuitry regulates self-renewal of embryonic stem cells. Nat Cell Biol, 10, 353-60.

KILENS, S., MEISTERMANN, D., MORENO, D., ChARIAU, C., GAIGNERIE, A., REIGNIER, A., LELIEVRE, Y., CASANOVA, M., VALLOT, C., NEDELLEC, S., FLIPPE, L., FIRMIN, J., SONG, J., ChARPENTIER, E., LAMMERS, J., DONNART, A., MAREC, N., DEB, W., BIHOUEE, A., LE CAIGNEC, C., PECQUEUR, C., REDON, R., BARRIERE, P., BOURDON, J., PASQUE, V., SOUMILLON, M., MIKKELSEN, T. S., ROUGEULLE, C., FREOUR, T., DAVID, L. \& MILIEU INTERIEUR, C. 2018. Parallel derivation of isogenic human primed and naive induced pluripotent stem cells. Nat Commun, 9, 360. 
KIM, S. K., LEE, H., HAN, K., KIM, S. C., CHOI, Y., PARK, S. W., BAK, G., LEE, Y., CHOI, J. K., KIM, T. K., HAN, Y. M. \& LEE, D. 2014. SET7/9 methylation of the pluripotency factor LIN28A is a nucleolar localization mechanism that blocks let-7 biogenesis in human ESCs. Cell Stem Cell, 15, 735-49.

KIMBER, S. J., SNEDDON, S. F., BLOOR, D. J., EL-BAREG, A. M., HAWKHEAD, J. A., METCALFE, A. D., HOUGHTON, F. D., LEESE, H. J., RUTHERFORD, A., LIEBERMAN, B. A. \& BRISON, D. R. 2008. Expression of genes involved in early cell fate decisions in human embryos and their regulation by growth factors. Reproduction, 135, 635-47. KOSICKI, M., TOMBERG, K. \& BRADLEY, A. 2018. Repair of double-strand breaks induced by CRISPR-Cas9 leads to large deletions and complex rearrangements. Nat Biotechnol, $36,765-771$.

LI, B. \& DEWEY, C. N. 2011. RSEM: accurate transcript quantification from RNA-Seq data with or without a reference genome. BMC Bioinformatics, 12, 323.

LINDSAY, H., BURGER, A., BIYONG, B., FELKER, A., HESS, C., ZAUGG, J., CHIAVACCI, E., ANDERS, C., JINEK, M., MOSIMANN, C. \& ROBINSON, M. D. 2016. CrispRVariants charts the mutation spectrum of genome engineering experiments. Nat Biotechnol, $34,701-2$.

LIU, X., NEFZGER, C. M., ROSSELLO, F. J., CHEN, J., KNAUPP, A. S., FIRAS, J., FORD, E., PFLUEGER, J., PAYNTER, J. M., CHY, H. S., O'BRIEN, C. M., HUANG, C., MISHRA, K., HODGSON-GARMS, M., JANSZ, N., WILLIAMS, S. M., BLEWITT, M. E., NILSSON, S. K., SCHITTENHELM, R. B., LASLETT, A. L., LISTER, R. \& POLO, J. M. 2017. Comprehensive characterization of distinct states of human naive pluripotency generated by reprogramming. Nat Methods.

LOEWER, S., CABILI, M. N., GUTTMAN, M., LOH, Y. H., THOMAS, K., PARK, I. H., GARBER, M., CURRAN, M., ONDER, T., AGARWAL, S., MANOS, P. D., DATTA, S., LANDER, E. S., SCHLAEGER, T. M., DALEY, G. Q. \& RINN, J. L. 2010. Large intergenic non-coding RNARoR modulates reprogramming of human induced pluripotent stem cells. Nat Genet, $42,1113-7$.

LOVE, M. I., HUBER, W. \& ANDERS, S. 2014. Moderated estimation of fold change and dispersion for RNA-seq data with DESeq2. Genome Biol, 15, 550.

MATHIEU, J., DETRAUX, D., KUPPERS, D., WANG, Y., CAVANAUGH, C., SIDHU, S., LEVY, S., ROBITAILLE, A. M., FERRECCIO, A., BOTTORFF, T., MCALISTER, A., SOMASUNDARAM, 
PENG, S., CHEN, L. L., LEI, X. X., YANG, L., LIN, H., CARMICHAEL, G. G. \& HUANG, Y. 2011.

L., ARTONI, F., BATTLE, S., HAWKINS, R. D., MOON, R. T., WARE, C. B., PADDISON, P. J. \& RUOHOLA-BAKER, H. 2019. Folliculin regulates mTORC1/2 and WNT pathways in early human pluripotency. Nat Commun, 10, 632.

MESSERSCHMIDT, D. M. \& KEMLER, R. 2010. Nanog is required for primitive endoderm formation through a non-cell autonomous mechanism. Dev Biol, 344, 129-37. MESSMER, T., VON MEYENN, F., SAVINO, A., SANTOS, F., MOHAMMED, H., LUN, A. T. L., MARIONI, J. C. \& REIK, W. 2019. Transcriptional Heterogeneity in Naive and Primed MITSUI, K., TOKUZAWA, Y., ITOH, H., SEGAWA, K., MURAKAMI, M., TAKAHASHI, K., MARUYAMA, M., MAEDA, M. \& YAMANAKA, S. 2003. The homeoprotein Nanog is required for maintenance of pluripotency in mouse epiblast and ES cells. Cell, 113, 631-42.

NAKAMURA, T., OKAMOTO, I., SASAKI, K., YABUTA, Y., IWATANI, C., TSUCHIYA, H., SEITA, Y., NAKAMURA, S., YAMAMOTO, T. \& SAITOU, M. 2016. A developmental coordinate of pluripotency among mice, monkeys and humans. Nature, 537, 57-62.

NIAKAN, K. K. \& EGGAN, K. 2013. Analysis of human embryos from zygote to blastocyst reveals distinct gene expression patterns relative to the mouse. Dev Biol, 375, 54-64. NICHOLS, J. \& SMITH, A. 2012. Pluripotency in the embryo and in culture. Cold Spring Harb Perspect Biol, 4, a008128.

NICKLESS, A., BAILIS, J. M. \& YOU, Z. 2017. Control of gene expression through the nonsense-mediated RNA decay pathway. Cell Biosci, 7, 26.

PARISI, S., PASSARO, F., ALOIA, L., MANABE, I., NAGAI, R., PASTORE, L. \& RUSSO, T. 2008. KIf5 is involved in self-renewal of mouse embryonic stem cells. J Cell Sci, 121, 262934.

PARK, J., LIM, K., KIM, J. S. \& BAE, S. 2017. Cas-analyzer: an online tool for assessing genome editing results using NGS data. Bioinformatics, 33, 286-288.

PASTOR, W. A., LIU, W., CHEN, D., HO, J., KIM, R., HUNT, T. J., LUKIANCHIKOV, A., LIU, X., POLO, J. M., JACOBSEN, S. E. \& CLARK, A. T. 2018. TFAP2C regulates transcription in human naive pluripotency by opening enhancers. Nat Cell Biol, 20, 553-564. Genome-wide studies reveal that Lin28 enhances the translation of genes important for growth and survival of human embryonic stem cells. Stem Cells, 29, 496-504. 
PETROPOULOS, S., EDSGARD, D., REINIUS, B., DENG, Q., PANULA, S. P., CODELUPPI, S., PLAZA REYES, A., LINNARSSON, S., SANDBERG, R. \& LANNER, F. 2016. Single-Cell RNA-Seq Reveals Lineage and X Chromosome Dynamics in Human Preimplantation Embryos. Cell, 165, 1012-26.

PRZEWROCKA, J., ROWAN, A., ROSENTHAL, R., KANU, N. \& SWANTON, C. 2020. Unintended on-target chromosomal instability following CRISPR/Cas9 single gene targeting. Ann Oncol, 31, 1270-1273.

QIN, H., HEJNA, M., LIU, Y., PERCHARDE, M., WOSSIDLO, M., BLOUIN, L., DURRUTHYDURRUTHY, J., WONG, P., QI, Z., YU, J., QI, L. S., SEBASTIANO, V., SONG, J. S. \& RAMALHO-SANTOS, M. 2016. YAP Induces Human Naive Pluripotency. Cell Rep, 14, 2301-12.

RAMOS-IBEAS, P., SANG, F., ZHU, Q., TANG, W. W. C., WITHEY, S., KLISCH, D., WOOD, L., LOOSE, M., SURANI, M. A. \& ALBERIO, R. 2019. Pluripotency and X chromosome dynamics revealed in pig pre-gastrulating embryos by single cell analysis. Nat Commun, 10, 500 .

RAN, F. A., HSU, P. D., WRIGHT, J., AGARWALA, V., SCOTT, D. A. \& ZHANG, F. 2013. Genome engineering using the CRISPR-Cas9 system. Nat Protoc, 8, 2281-308.

RAYNER, E., DURIN, M.-A., THOMAS, R., MORALLI, D., O'CATHAIL, S. M., TOMLINSON, I., GREEN, C. M. \& LEWIS, A. 2019. CRISPR-Cas9 Causes Chromosomal Instability and Rearrangements in Cancer Cell Lines, Detectable by Cytogenetic Methods. The CRISPR Journal, 2, 406-416.

ROSSANT, J. 2016. Making the Mouse Blastocyst: Past, Present, and Future. Curr Top Dev Biol, 117, 275-88.

ROSTOVSKAYA, M., STIRPARO, G. G. \& SMITH, A. 2019. Capacitation of human naive pluripotent stem cells for multi-lineage differentiation. Development, 146.

SAEZ, I., KOYUNCU, S., GUTIERREZ-GARCIA, R., DIETERICH, C. \& VILCHEZ, D. 2018. Insights into the ubiquitin-proteasome system of human embryonic stem cells. Sci Rep, 8, 4092.

SARBASSOV, D. D., GUERTIN, D. A., ALI, S. M. \& SABATINI, D. M. 2005. Phosphorylation and regulation of Akt/PKB by the rictor-mTOR complex. Science, 307, 1098-101.

SHAHBAZI, M. N., SCIALDONE, A., SKORUPSKA, N., WEBERLING, A., RECHER, G., ZHU, M., JEDRUSIK, A., DEVITO, L. G., NOLI, L., MACAULAY, I. C., BUECKER, C., KHALAF, Y., ILIC, 

transitions coordinate morphogenesis in mouse and human embryos. Nature, 552, 239-243.

SINGH, A. M., REYNOLDS, D., CLIFF, T., OHTSUKA, S., MATTHEYSES, A. L., SUN, Y., MENENDEZ, L., KULIK, M. \& DALTON, S. 2012. Signaling network crosstalk in human pluripotent cells: a Smad2/3-regulated switch that controls the balance between self-renewal and differentiation. Cell Stem Cell, 10, 312-26.

STIRPARO, G. G., BOROVIAK, T., GUO, G., NICHOLS, J., SMITH, A. \& BERTONE, P. 2018. Integrated analysis of single-cell embryo data yields a unified transcriptome signature for the human preimplantation epiblast. Development.

TAKAHASHI, K. \& YAMANAKA, S. 2006. Induction of pluripotent stem cells from mouse embryonic and adult fibroblast cultures by defined factors. Cell, 126, 663-76.

TAKASHIMA, Y., GUO, G., LOOS, R., NICHOLS, J., FICZ, G., KRUEGER, F., OXLEY, D., SANTOS, F., CLARKE, J., MANSFIELD, W., REIK, W., BERTONE, P. \& SMITH, A. 2014. Resetting transcription factor control circuitry toward ground-state pluripotency in human. Cell, 158, 1254-69.

THEUNISSEN, T. W., POWELL, B. E., WANG, H., MITALIPOVA, M., FADDAH, D. A., REDDY, J., FAN, Z. P., MAETZEL, D., GANZ, K., SHI, L., LUNGJANGWA, T., IMSOONTHORNRUKSA, S., STELZER, Y., RANGARAJAN, S., D'ALESSIO, A., ZHANG, J., GAO, Q., DAWLATY, M. M., YOUNG, R. A., GRAY, N. S. \& JAENISCH, R. 2014. Systematic identification of culture conditions for induction and maintenance of naive human pluripotency. Cell Stem Cell, 15, 471-87.

VAN VLIET, J., CROFTS, L. A., QUINLAN, K. G., CZOLIJ, R., PERKINS, A. C. \& CROSSLEY, M. 2006. Human KLF17 is a new member of the Sp/KLF family of transcription factors. Genomics, 87, 474-82.

VISWANATHAN, S. R., DALEY, G. Q. \& GREGORY, R. I. 2008. Selective blockade of microRNA processing by Lin28. Science, 320, 97-100.

WAMAITHA, S. E., DEL VALLE, I., CHO, L. T., WEI, Y., FOGARTY, N. M., BLAKELEY, P., SHERWOOD, R. I., JI, H. \& NIAKAN, K. K. 2015. Gata6 potently initiates reprograming of pluripotent and differentiated cells to extraembryonic endoderm stem cells. Genes Dev, 29, 1239-55. 
WAMAITHA, S. E., GRYBEL, K. J., ALANIS-LOBATO, G., GERRI, C., OGUSHI, S., MCCARTHY, A., MAHADEVAIAH, S. K., HEALY, L., LEA, R. A., MOLINA-ARCAS, M., DEVITO, L. G., ELDER, K., SNELL, P., CHRISTIE, L., DOWNWARD, J., TURNER, J. M. A. \& NIAKAN, K. K. 2020. IGF1-mediated human embryonic stem cell self-renewal recapitulates the embryonic niche. Nat Commun, 11, 764.

WANG, X., LIU, D., HE, D., SUO, S., XIA, X., HE, X., HAN, J. J. \& ZHENG, P. 2017. Transcriptome analyses of rhesus monkey preimplantation embryos reveal a reduced capacity for DNA double-strand break repair in primate oocytes and early embryos. Genome Res, 27, 567-579.

WANG, Y., XU, Z., JIANG, J., XU, C., KANG, J., XIAO, L., WU, M., XIONG, J., GUO, X. \& LIU, H. 2013. Endogenous miRNA sponge lincRNA-RoR regulates Oct4, Nanog, and Sox 2 in human embryonic stem cell self-renewal. Dev Cell, 25, 69-80.

WANG, Z., ORON, E., NELSON, B., RAZIS, S. \& IVANOVA, N. 2012. Distinct lineage specification roles for NANOG, OCT4, and SOX2 in human embryonic stem cells. Cell Stem Cell, 10, 440-54.

WANI, M. A., MEANS, R. T., JR. \& LINGREL, J. B. 1998. Loss of LKLF function results in embryonic lethality in mice. Transgenic Res, 7, 229-38.

YAMANE, M., OHTSUKA, S., MATSUURA, K., NAKAMURA, A. \& NIWA, H. 2018. Overlapping functions of Kruppel-like factor family members: targeting multiple transcription factors to maintain the naive pluripotency of mouse embryonic stem cells. Development, 145.

YAN, L., YANG, M., GUO, H., YANG, L., WU, J., LI, R., LIU, P., LIAN, Y., ZHENG, X., YAN, J., HUANG, J., LI, M., WU, X., WEN, L., LAO, K., LI, R., QIAO, J. \& TANG, F. 2013. Singlecell RNA-Seq profiling of human preimplantation embryos and embryonic stem cells. Nat Struct Mol Biol, 20, 1131-9.

YU, J., VODYANIK, M. A., SMUGA-OTTO, K., ANTOSIEWICZ-BOURGET, J., FRANE, J. L., TIAN, S., NIE, J., JONSDOTTIR, G. A., RUOTTI, V., STEWART, R., SLUKVIN, II \& THOMSON, J. A. 2007. Induced pluripotent stem cell lines derived from human somatic cells. Science, 318, 1917-20.

ZHOU, S., TANG, X. \& TANG, F. 2016. Kruppel-like factor 17, a novel tumor suppressor: its low expression is involved in cancer metastasis. Tumour Biol, 37, 1505-13. 
ZIMMERLIN, L., PARK, T. S., HUO, J. S., VERMA, K., PATHER, S. R., TALBOT, C. C., JR., AGARWAL, J., STEPPAN, D., ZHANG, Y. W., CONSIDINE, M., GUO, H., ZHONG, X., GUTIERREZ, C., COPE, L., CANTO-SOLER, M. V., FRIEDMAN, A. D., BAYLIN, S. B. \& ZAMBIDIS, E. T. 2016. Tankyrase inhibition promotes a stable human naive pluripotent state with improved functionality. Development, 143, 4368-4380.

\section{Figure Legends}

Figure 1 - KLF17 expression in the human embryo is coincident with known pluripotency

factors. Representative images of immunofluorescence analysis of blastocyst stage human embryos at early day $5(N=5)$, late day $5(N=7)$, early day $6(N=9)$, late day $6(N=5)$ and early day $7(N=$ 5) post-fertilisation. Scale bars $=50 \mu \mathrm{m}$.

\section{Figure 2 - Exogenous KLF17 overexpression induces naïve factor expression in conventional} hESCs. (A) Schematic diagram of generating H9 KLF17-HA inducible hESCs via lentiviral transduction. (B) Immunofluorescence analysis of H9 KLF17-HA inducible hESCs following 5 days uninduced (UI) or 5 days doxycycline (Dox) induction (+Dox). Scale bars $=20 \mu \mathrm{m}$. N $\geq 3$. (C) qRTPCR analysis of H9 KLF17-HA inducible hESCs following 5 days with (+Dox) or without (-Dox) Dox induction of exogenous KLF17. Relative expression is displayed as fold change versus uninduced cells and normalised to GAPDH as a housekeeping gene using the $\triangle \triangle \mathrm{Ct}$ method. Individual samples are shown as dots, lines represent the mean and whiskers the SEM. Welch's $t$ test, ${ }^{* * *} p<0.005,{ }^{*} p$ $<0.05$.

\section{Figure 3 - Exogenous KLF17 overexpression induces widespread transcriptional change in} conventional hESCs. (A) Dimensionality reduction by principal component analysis (PCA) of bulk RNA-seq data collected across a 5-day time course of H9 KLF17-HA inducible hESC growth with (+Dox) or without (UI) Dox induction of exogenous KLF17 expression. (B) Volcano plot displaying relative expression of all detected genes in +Dox versus UI H9 KLF17-HA hESCs at day 5 (logFC(+Dox Day5 vs UI Day5)) against the significance of differential expression (-log10(padjust)). The red dotted line notes $p_{a d j}=0.05$. Individual genes of interest are displayed as filled circles and labelled with the gene name. (C-D) Normalised expression (transcripts per million, TPM) of individual genes of interest across the 5-day time course in uninduced control (UI) and KLF17-expressing (+Dox) H9 KLF17-HA hESCs, showing gene that are significantly upregulated (C) or downregulated (D) at day 5. (E) Heatmap grouped by sample (UI or +Dox) and time point showing the genes that are highly correlated with KLF17 across time (Pearson correlation coefficient $\geq 0.85$ ) and fall under the Kyoto Encyclopaedia of Genes and Genomes (KEGG) category "PI3K-Akt signalling pathway". (F) Immunofluorescence analysis of H9 KLF17-HA inducible hESCs following 5 days uninduced (UI) or 5 days doxycycline induction (+Dox). Scale bars $=20 \mu \mathrm{m} . \mathrm{N} \geq 3$. 
1143 Figure 4 - Exogenous KLF17 overexpression is sufficient to drive conventional hESCs to a

1144 naïve pluripotent state under PXGL culture. (A) Immunofluorescence analysis H9 KLF17-HA

1145 inducible hESCs following 5 days uninduced (UI) or 5 days doxycycline induction (+Dox) in the

1146 indicated media. Cells were cultured on a mouse embryonic fibroblast (MEF) feeder layer and at $5 \%$

$1147 \mathrm{O}_{2}$. Scale bars $=20 \mu \mathrm{m}$. $\mathrm{N} \geq 3$. (B) Cells induced for 5 days in PXGL medium were uniquely able to

1148 give rise to typical naïve hESC-like colonies following serial bulk passaging. (C) Representative

1149 immunofluorescence analysis of H9 KLF17-HA induced naive hESCs after 4 or 5 passages in PXGL

1150 medium. Scale bars $=20 \mu \mathrm{m} . \mathrm{N} \geq 3$.

1151

1152 Figure 5 - Generating KLF17-null mutant hESCs by CRISPR-Cas9. (A) Schematic representation

1153 of the human KLF17 locus on Chromosome 1, showing the relative position of the DNA-binding zinc

1154 finger domains (filled black rectangles) and the guide RNAs (gRNAs) tested for mutagenic efficiency.

1155 Exons are shown as red rectangles, 3' and 5' UTR are unfilled rectangles and introns are black

1156 chevrons. (B) Relative efficiency of each guide shown in (A) measured as a proportion of overall

1157 reads containing indel mutations following on-target amplification by MiSeq of the KLF17 target site.

1158 Dots represent individual harvested wells of CRISPR-targeted H9 hESCs, lines represent the mean

1159 and whiskers the SEM. (C) Pie charts representing the relative proportions of different outcomes of

1160 CRISPR-Cas9 editing of H9 hESCs, based on the sequences detected by MiSeq analysis. (D)

1161 Immunofluorescence analysis of H9 hESCs targeted with Cas9 and gRNA KLF17(3_1) by

1162 nucleofection of a plasmid, following subjection to the epigenetic resetting protocol (Guo et al., 2017)

1163 for 8 days. Internal wild-type (WT) controls (\#7, \#15 and \#21) are clones that were subjected to

1164 nucleofection, puromycin selection and clonal expansion, but were unedited, with a wild-type

1165 genotype. Compound null mutant clones (\#18 and \#19) were verified by MiSeq and IF. N = 3.

1166

1167 Figure 6 - KLF17-null hESCs are capable of attaining and maintaining naïve pluripotency. (A)

1168 Representative brightfield images of WT and $K L F 17^{-1-} \mathrm{H} 9 \mathrm{hESC}$ following 10 passages under naïve

1169 culture conditions. (B) Dimensionality reduction by principal component analysis (PCA) of bulk RNA-

1170 seq data collected at various times during the epigenetic resetting (Guo et al., 2017) of WT and

1171 KLF17 $7^{-1-}$ H9 hESCs. (C-F) Normalised expression (TPM) of individual genes of interest across the full

1172 resetting time course showing (C) lack of appreciable KLF17 transcripts, (D) temporally-limited

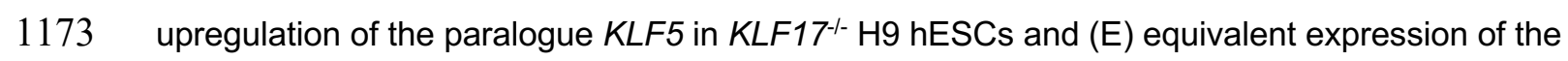

1174 paralogues KLF2 and (F) KLF4. (G) Volcano plot displaying relative expression of all detected genes



1176 (logFC(KLF17-- p5 vs WT p5)) against the significance of differential expression (-log10(padjust)).

1177 The red dotted line notes $p_{\text {adj }}=0.05$. Individual genes of interest are displayed as filled circles and

1178 labelled with the gene name. (H-I) Normalised expression (TPM) of individual genes of interest across

1179 the full resetting time course showing downregulation of $(\mathrm{H})$ the pluripotency-associated factor

1180 LIN28A and (I) the WNT signalling receptor FZD5 in KLF17-1- H9 hESCs.

1181 
1182 Figure S1 - KLF17 expression in the human embryo is coincident with known pluripotency

1183 factors. Immunofluorescence analysis of blastocyst stage human embryos at early day $5(\mathrm{~N}=5)$, late 1184 day $5(N=7)$, early day $6(N=9)$, late day $6(N=5)$ and early day $7(N=5)$ post-fertilisation. Scale 1185 bars $=50 \mu \mathrm{m}$.

Figure S2 - 70 genes are strongly correlated with KLF17 expression over time. (A) Heatmap ordered by sample (UI or +Dox) and time point showing all genes that are highly correlated with KLF17 across time (Pearson correlation coefficient $\geq 0.85$ ). (B-C) Volcano plots displaying relative expression of all detected genes in +Dox versus UI H9 KLF17-HA hESCs at (B) day 1 (logFC(+Dox Day1 vs UI Day1)) and (C) day 2 (logFC(+Dox Day1 vs UI Day1)) against the significance of differential expression (-log10(padjust)). The red dotted line notes $p_{a d j}=0.05$. Individual genes with correlation coefficient to $K L F 17 \geq 0.85$ are displayed as filled circles. genes of interest across the 5-day time course showing factors involved in (A-G) PI3K-AKT signalling, $(\mathrm{H}-\mathrm{I})$ TGF $\beta$ signalling, (J-L) other signalling pathways, (F-G,M-O) the cytoskeleton/ICM and $(\mathrm{P})$ the pluripotency-regulating long non-coding RNA LINC-ROR. (Q) Western blot showing KLF17 induction following 5 days Dox treatment of H9 KLF17-HA and associated expression of PI3K-AKT signalling factors. KLF17. (A-F) qRT-PCR analysis across the 5-day time course of Dox treatment in H9 KLF17-HA hESCs. Relative expression is displayed as fold change versus uninduced cells and normalised to $G A P D H$ as a housekeeping gene using the $\triangle \triangle \mathrm{Ct}$ method. Dots represent the mean and whiskers the SEM. Welch's $t$ test, ${ }^{* * *} p<0.001,{ }^{* * *} p<0.005,{ }^{* *} p<0.01,{ }^{*} p<0.05$. (G) Immunofluorescence analysis of H9 KLF17-HA inducible hESCs following 5 days uninduced (UI) or 5 days doxycycline (Dox) induction (+Dox). Scale bars $=20 \mu \mathrm{m} . \mathrm{N} \geq 3$.

1212 hESCs (A) Immunofluorescence analysis H9 KLF17-HA inducible hESCs following 5 days uninduced 1213 (UI) or 5 days doxycycline induction (+Dox) in the indicated media. Cells were cultured on a mouse 1214 embryonic fibroblast (MEF) feeder layer and at $5 \% \mathrm{O}_{2}$. Scale bars $=20 \mu \mathrm{m} . \mathrm{N} \geq 3$. (B) Unlike induced 1215 cells, uninduced control H9 KLF17-HA (UI) were unable to survive in PXGL medium following the first passage.

1218 Figure S6 - Generating KLF17-null hESCs by CRISPR-Cas9. (A) A table showing the gRNA 1219 sequences tested for mutagenic efficiency. (B) Pie charts representing the relative proportions of 1220 different outcomes of CRISPR-Cas9 editing of H9 hESCs, based on the sequences detected by 1221 MiSeq. 
1223 Figure S7 - Genotyping of H9 hESCs following targeting with gRNA KLF17(3_1) and clonal

1224 expansion. (A) A table showing the results of genotyping 11 clones generated following CRISPR-

1225 Cas9 targeting. Short-range genotype denotes the results of MiSeq of a $\sim 250$ bp region surrounding

1226 the KLF17(3_1) cut site. Long-range genotype denotes the results of Sanger sequencing of a 950 bp

1227 region surrounding the KLF17(3_1) cut site. The red rectangle highlights the verified $K L F 17^{-1-} \mathrm{H} 9$

1228 hESCs that were carried forward. (B) Schematic of the short- and long-range genotyping approach

1229 employed on the 11 clones in part (A). (C) A table showing the percentage of interpretable reads that

1230 showed one of two possible variant-types at the highly polymorphic regions illustrated in (B) -

1231 rs35084281 and rs34057178. Parental H9 is the unmodified control cell line, \#7 is an internal wild-

1232 type control clone generated following nucleofection of KLF17(3_1), \#1, \#8, \#9, 10 and \#11 are the

1233 KLF17-targeted $\mathrm{H} 9$ clones that appeared to have undergone homozygous editing based on short-

1234 range genotyping. (D-F) Illustration of the sequence context surrounding the KLF17(3_1) cut site in

1235 (D) the wild-type reference sequence, $(E)$ the case of an 8 bp deletion and $(F)$ the case of a $1 \mathrm{bp}$

1236 insertion. Important features of the KLF17 sequence are highlighted. DNA sequence is shown in

1237 regular font, amino acid sequence is bold above or below the DNA.

1239 Figure S8 - KLF17-null naïve hESCs at passage 5 display misregulated expression of core

1240 glycolytic enzymes and WNT pathway components. Normalised expression (TPM) of individual

1241 genes of interest across the resetting protocol showing (A-F) downregulation of glycolytic enzymes

1242 and (G-H) upregulation of WNT signalling factors. 
bioRxiv preprint doi: https://doi.org/10.1101/2020.12.18.423466; this version posted December 18,2020 . The copyright holder for this Kreprint (which was not certified by peer review) is the aythor/ffunder, who has granted bioRxiv a license to display the preprint in 

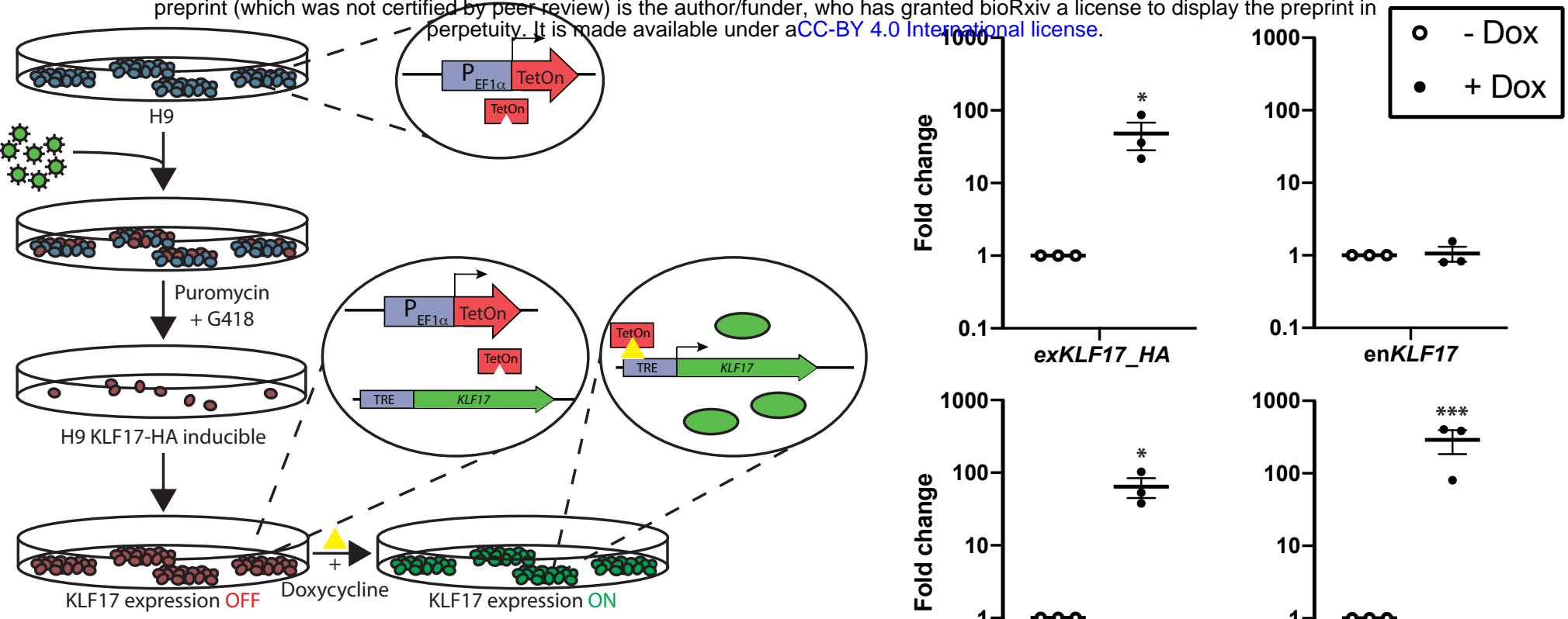

B.

KLF17

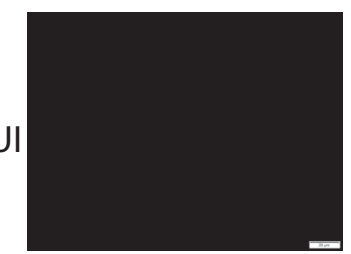

+Dox

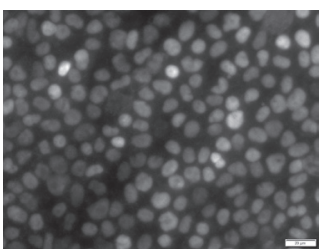

HA tag

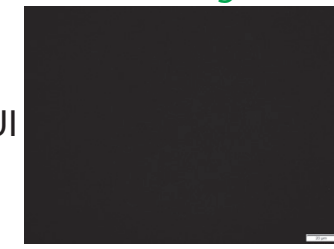

+ Dox
NANOG
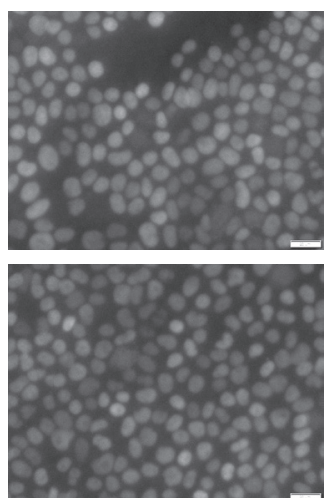

OCT4
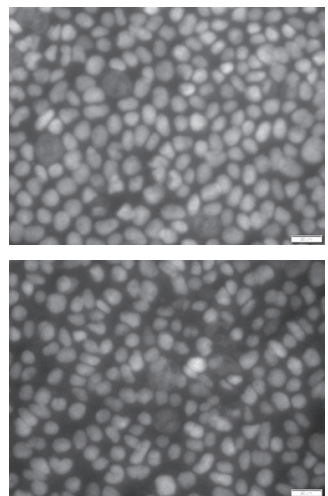

DAPI merge
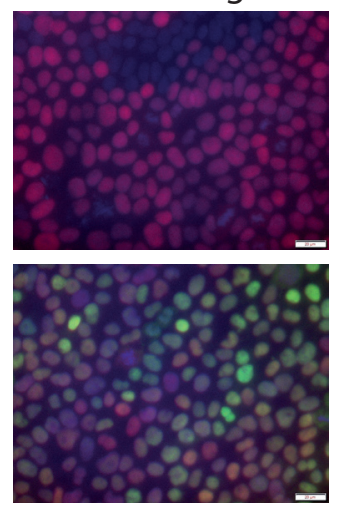

DAPI merge
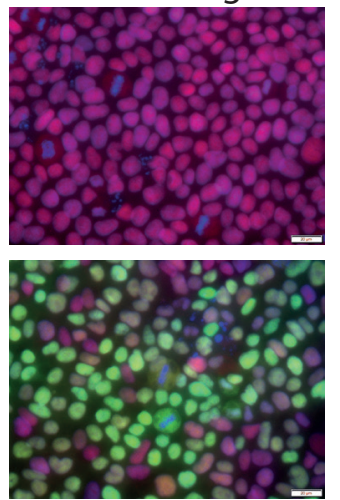
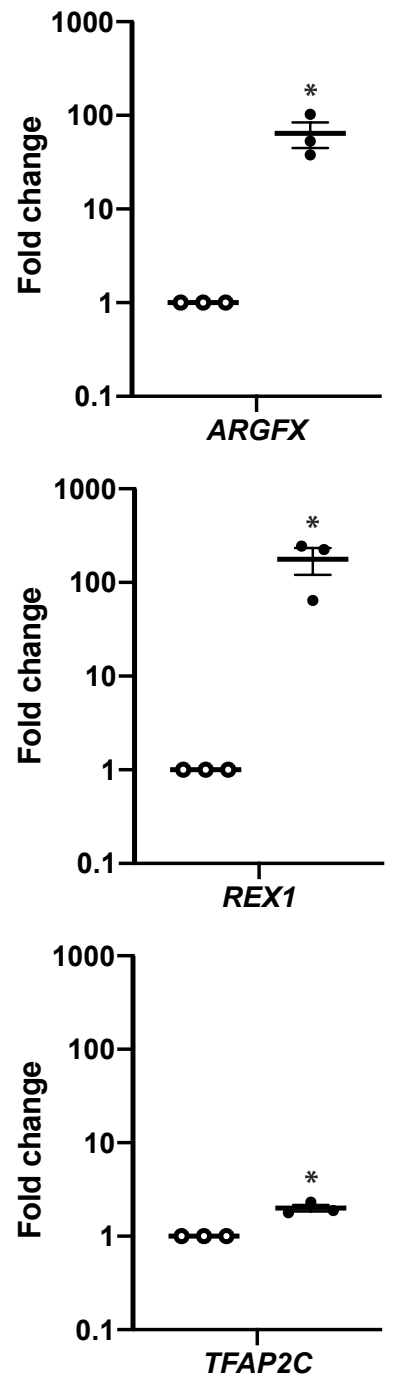
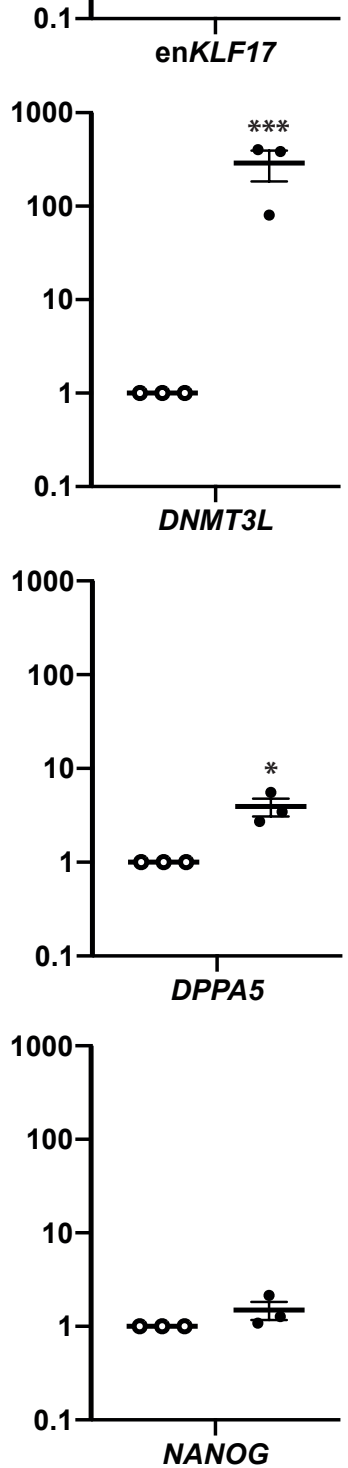
A.

bioRxiv preprint doi: https://doi.org/10.1101/2020.12.18.423466; this version posted December 18,2020 . The copyright holder for this preprint (which was not certified by peer review) is the author/funder, who has granted bioRxit aylicense to display the preprint in


KLF17(1_1)
$\operatorname{KLF} 17(3-1)$

$\overline{1}$

Exon 1

KLF17(1_2)

B.

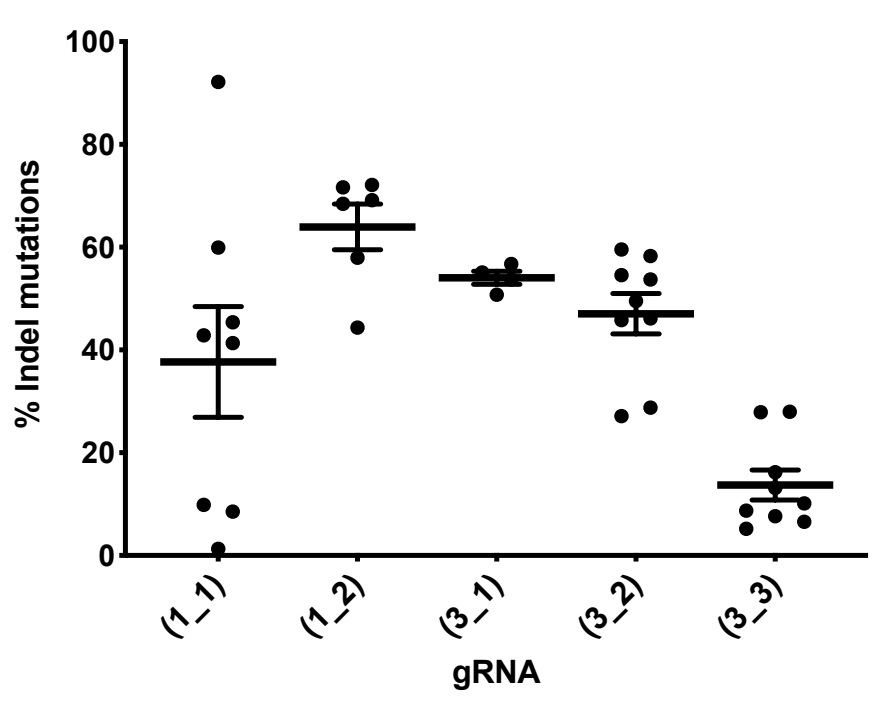

C.

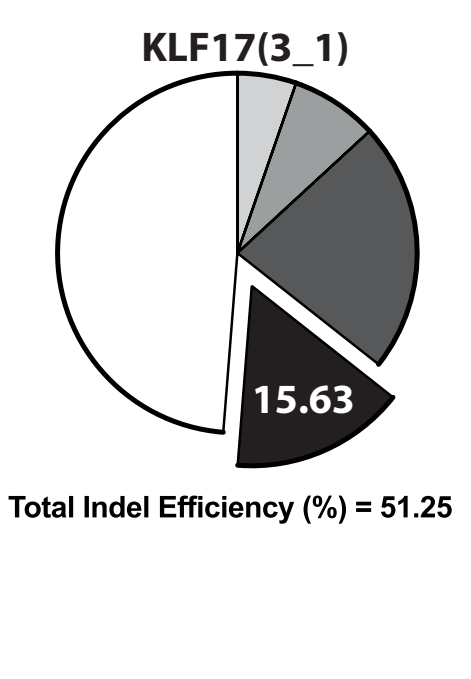

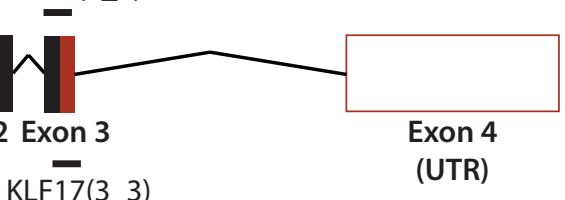

D.

\section{7: WT.1}

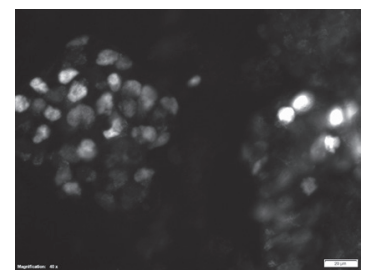

OCT4

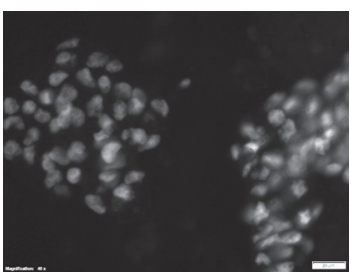

DAPI

merge
15: WT.2
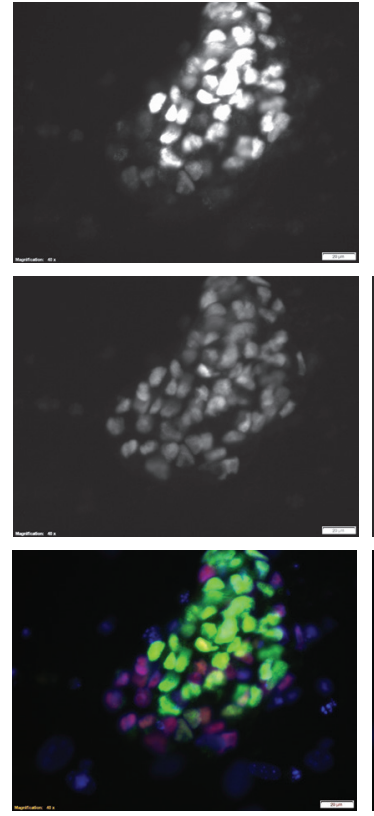

21: WT.3
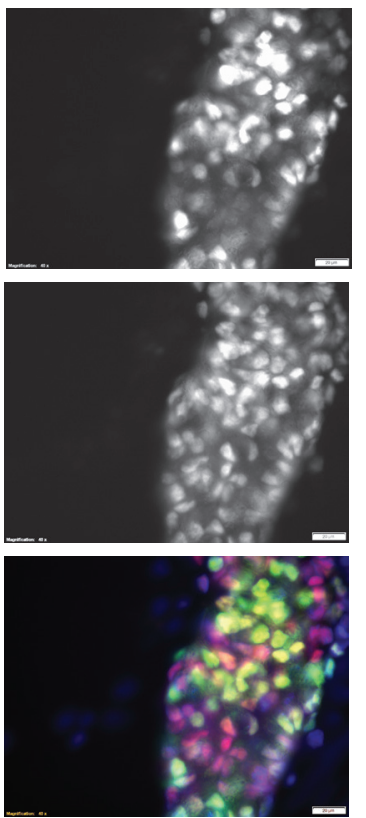

18: $(+1 / \Delta 8) .1$
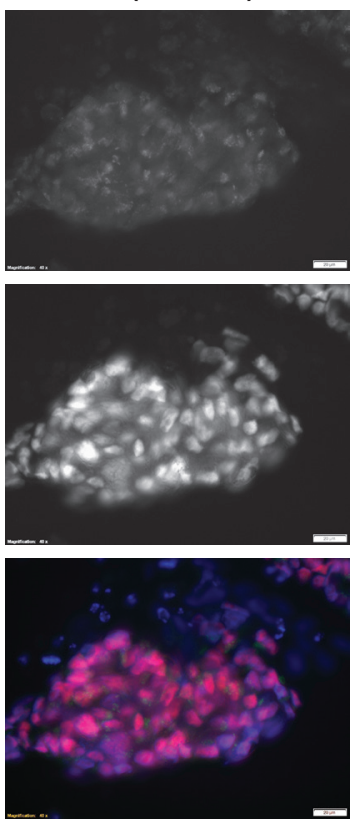

$<10 b p$ in-frame $>10$ bp in-frame

$<10 b p$ framshift

$>10$ bp frameshift $\square$ No indel

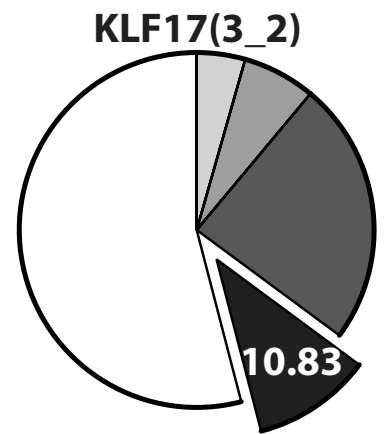

Total Indel Efficiency $(\%)=45.9556$

A. bioRxiv preprint doi: https://doi.org/10.1101/2020.12.18.423466; this version posted December 18,2020 . The copyright holder for this 7: WProprint (which was not certified by peer review) is the aythor/funder, who has granted bigRxiv a license to display the preprint in


Naive

passage 10

B.

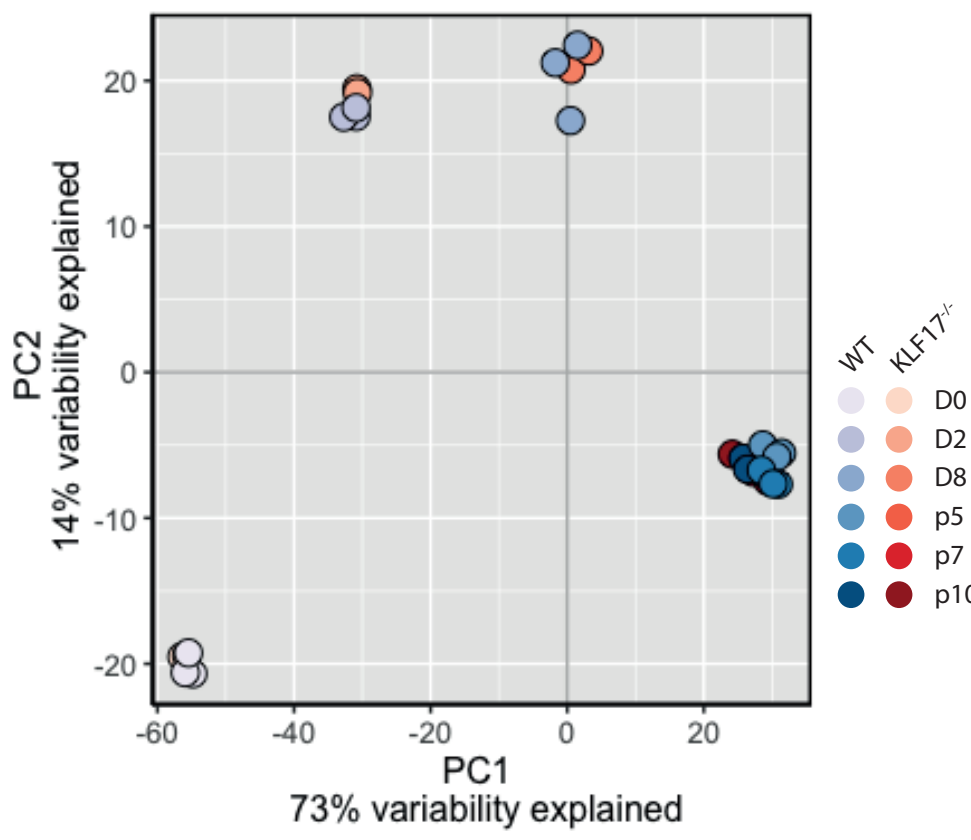

G.

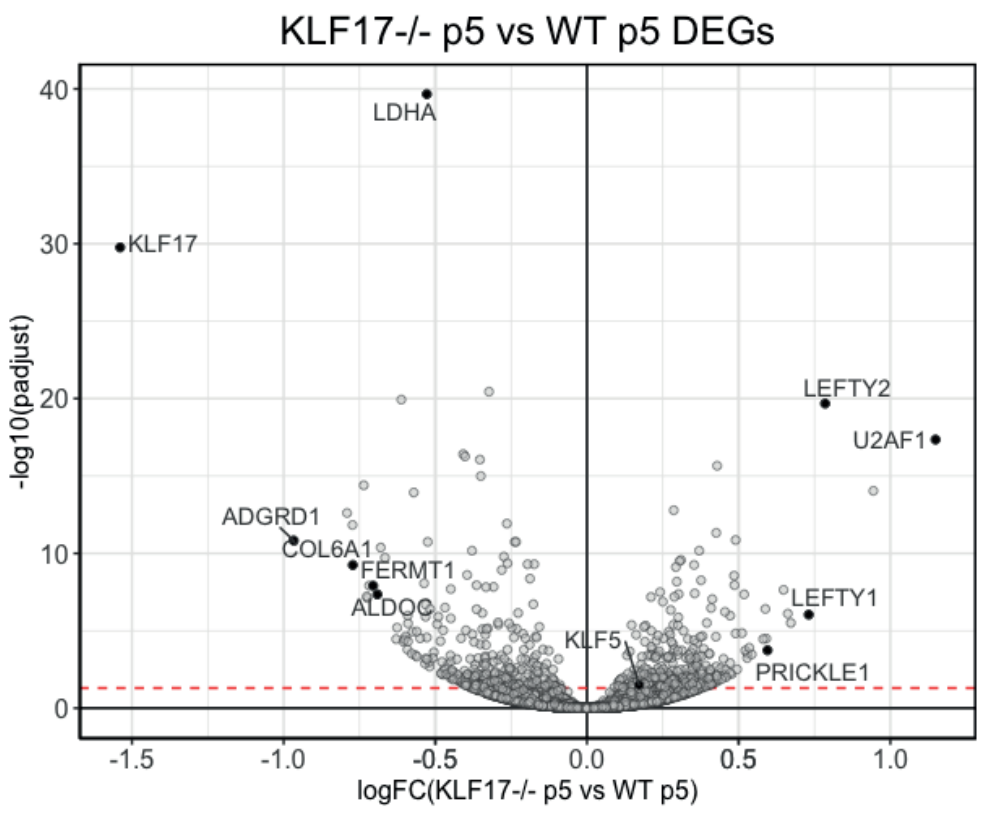

C.

D.

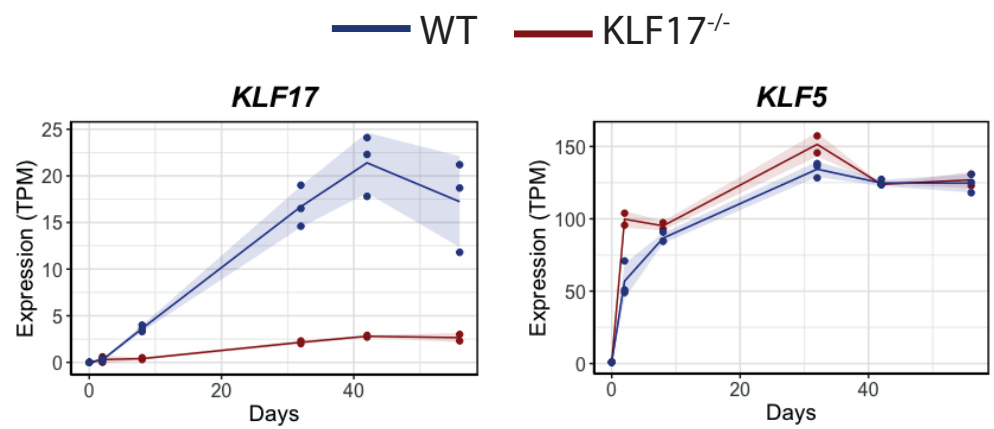

E.

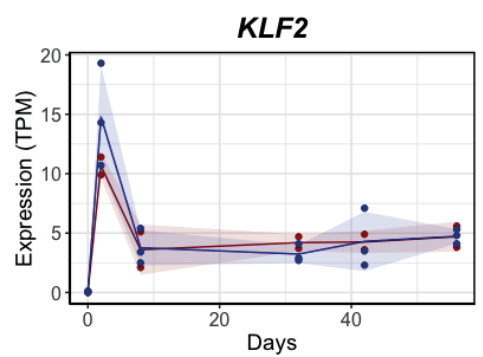

F.

$\mathrm{H}$.

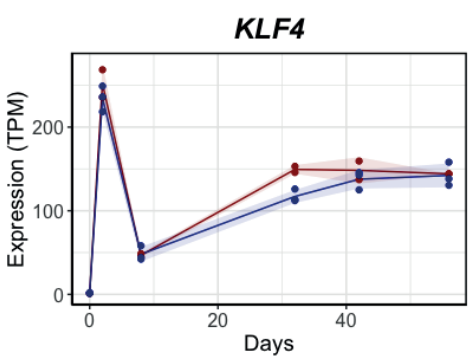

LIN28A
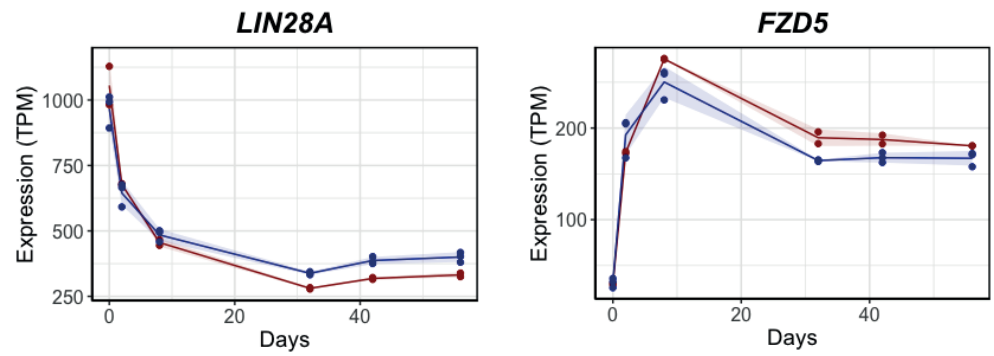
A.

A.

bioRxiv preprint doi: https://doi.org/10.1101/2020.12.18.423466; this version posted December 18, 2020. The copyright holder for this preprint (which was not certified by peer review) is the author/funder, who has granted bioRxiv a license to display the preprint in

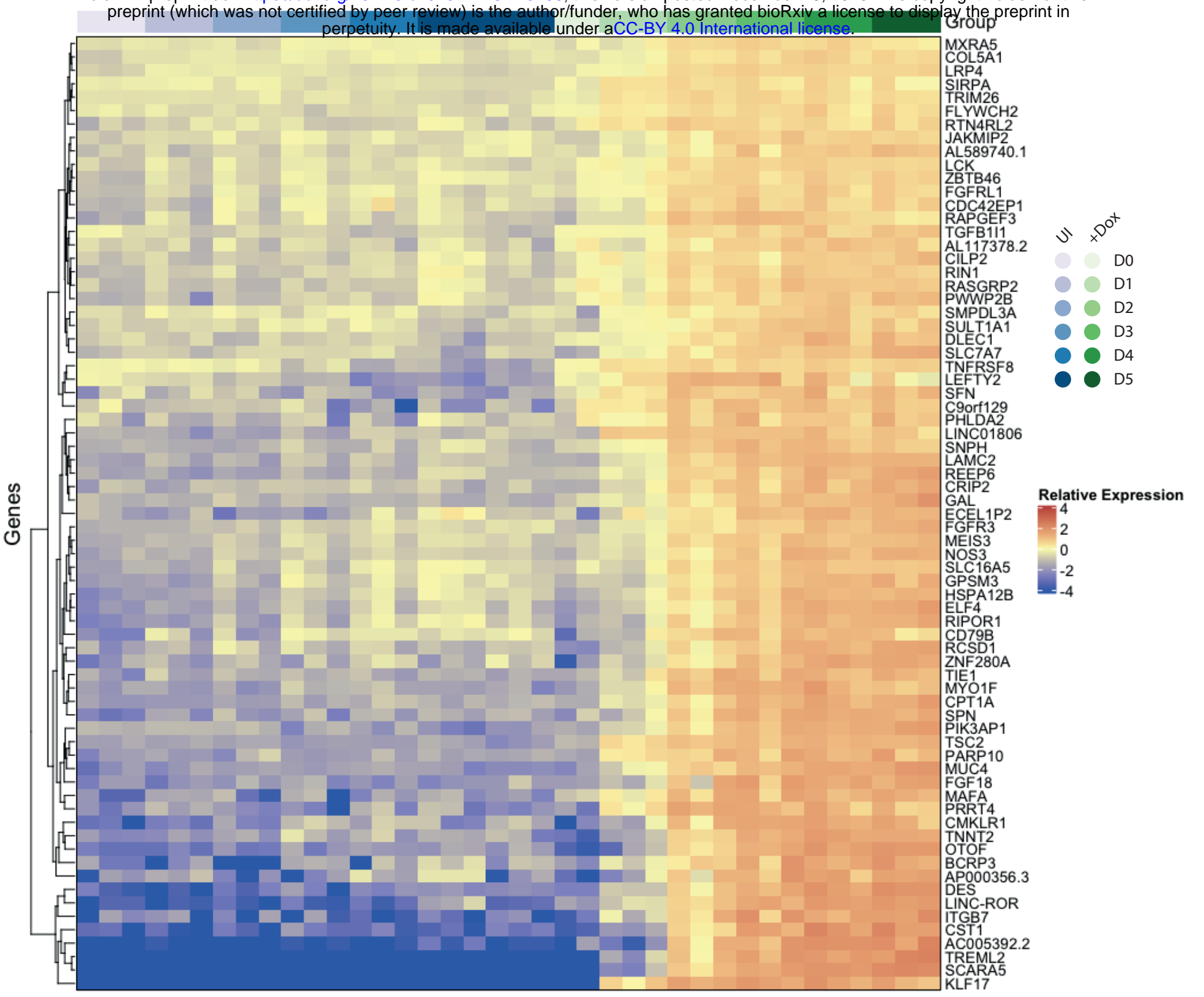

B.

+Dox Day 1 vs UI Day 1 DEGs, Corr $>0.85$

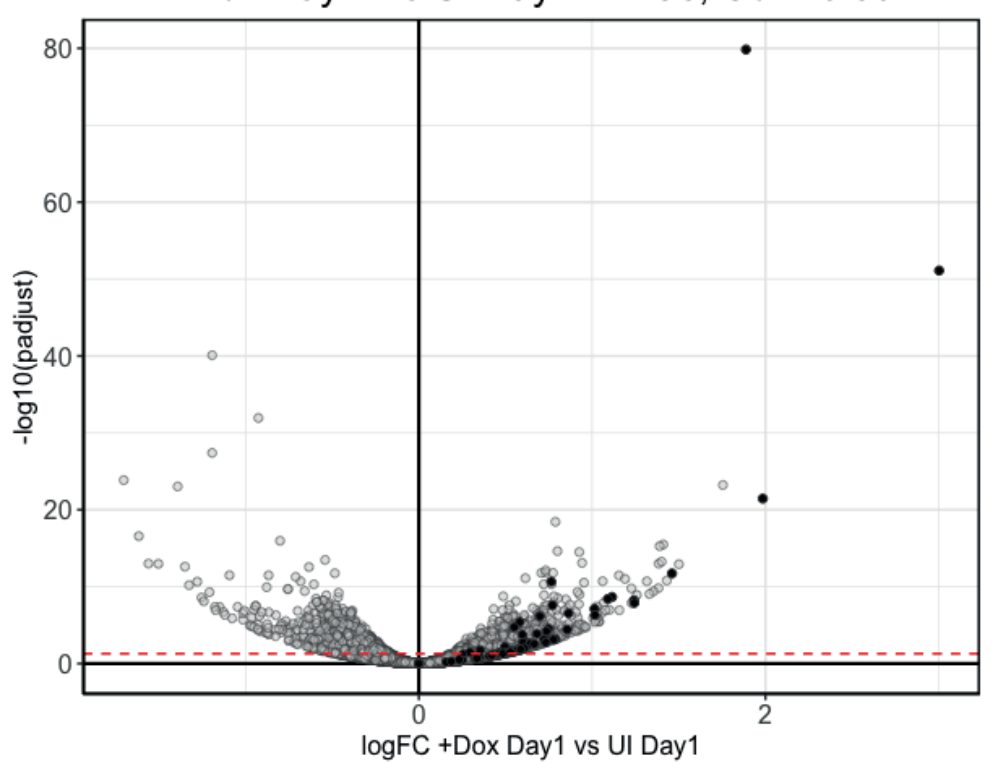

C.




A.

bioRxiv preprint doi: httpsB/doi.org/10.1101/2020.12.18.423466; thisCversion posted December 18, 2020. The Copyright holder for this



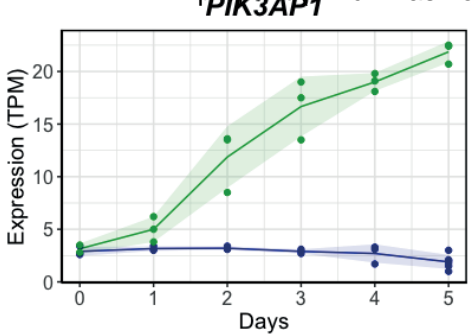

E.



I.



M.



N.

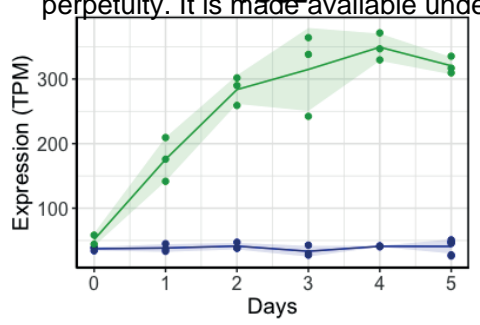

F.

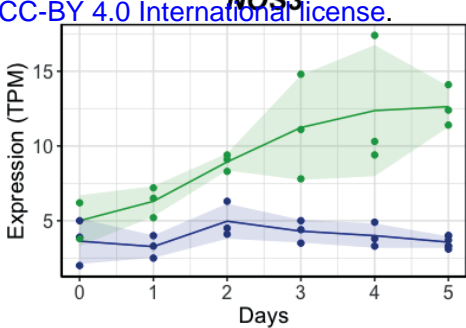

G.

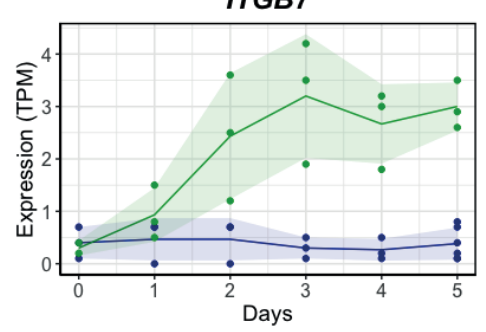

J.
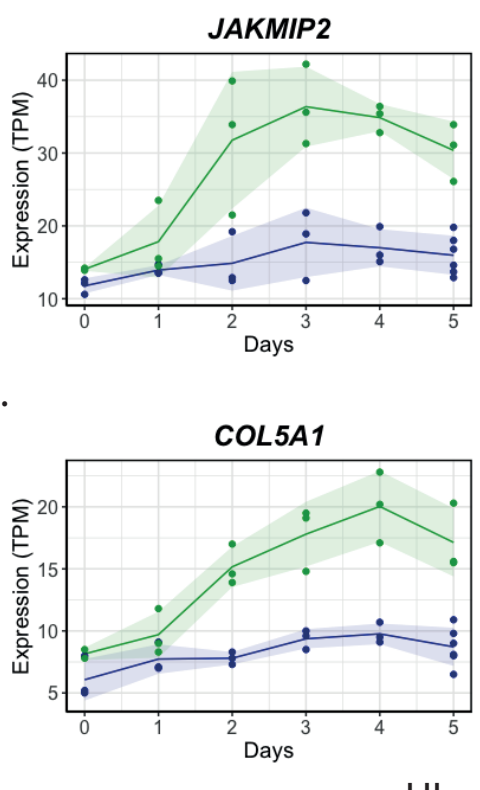

O.

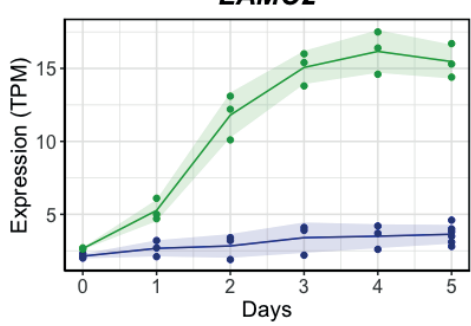

K.
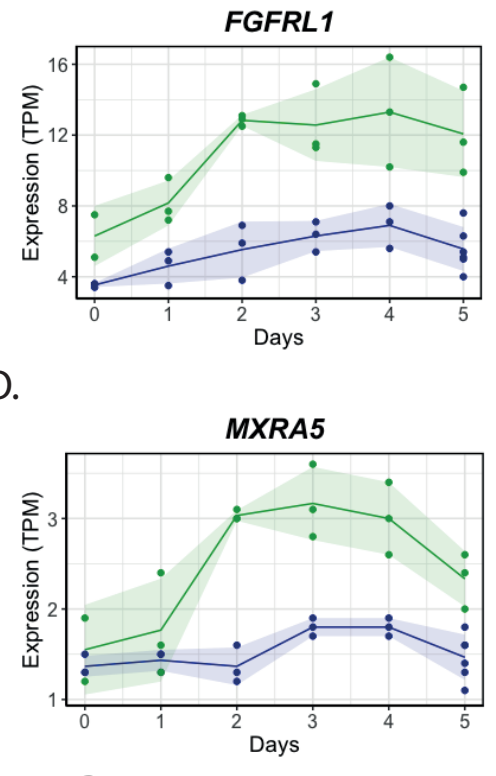

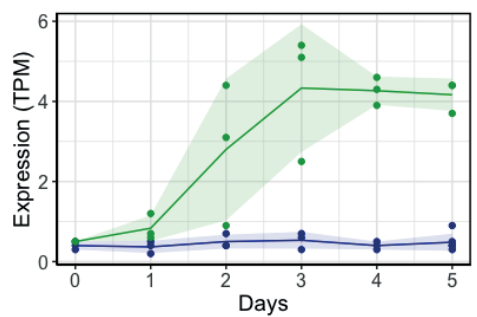

$\mathrm{H}$.



L.

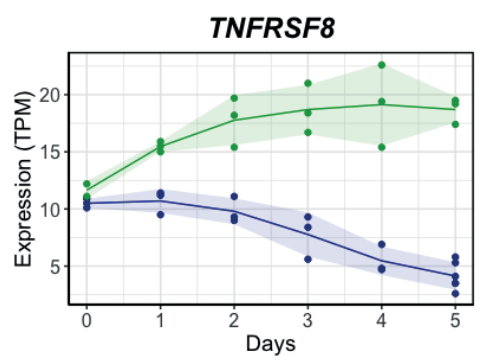

P.

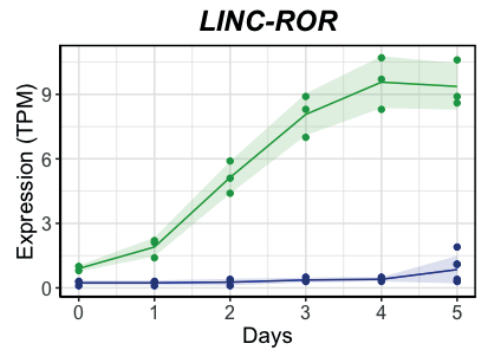

Q.

Day 5

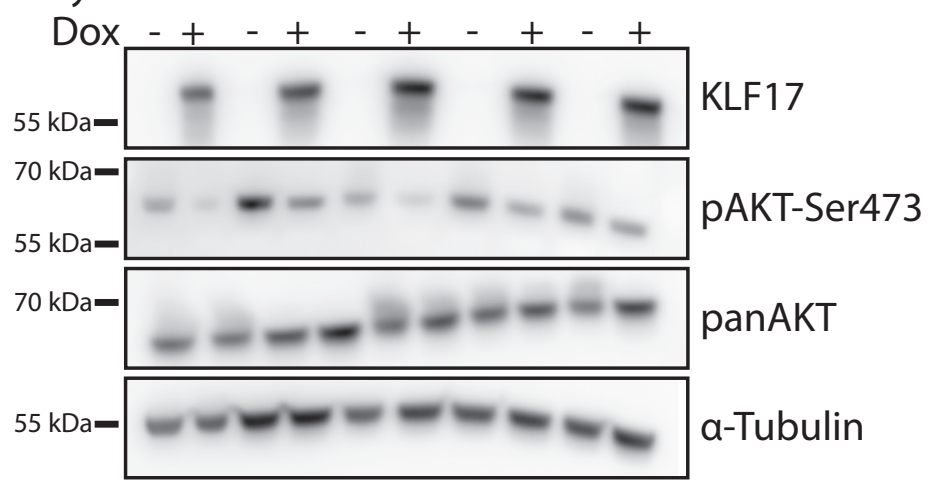


A.

A.

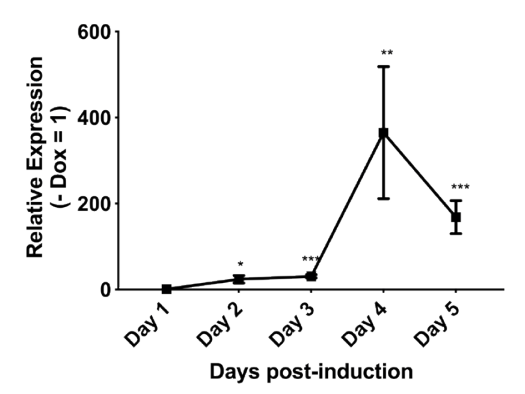

D.

ARGFX

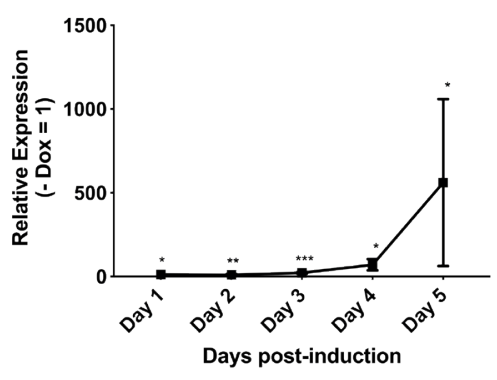

G.



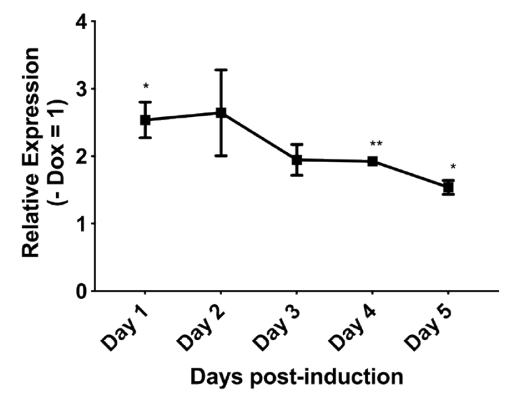

F.

REX1
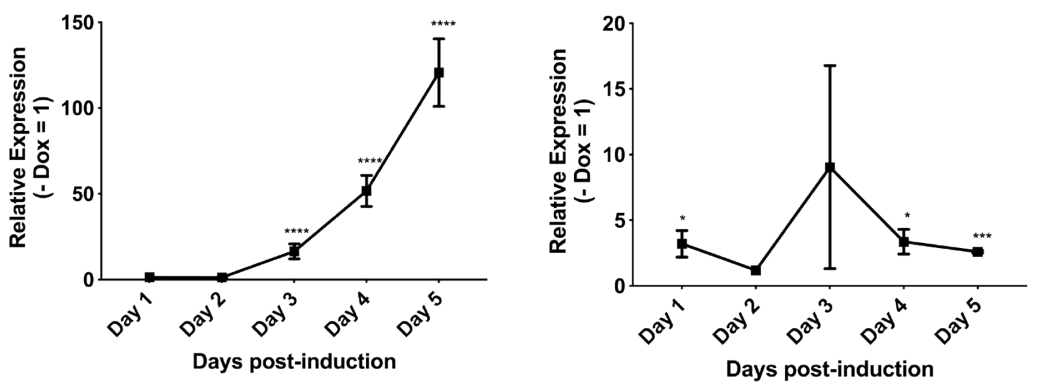

VENTX

HA

\section{DAPI merge}
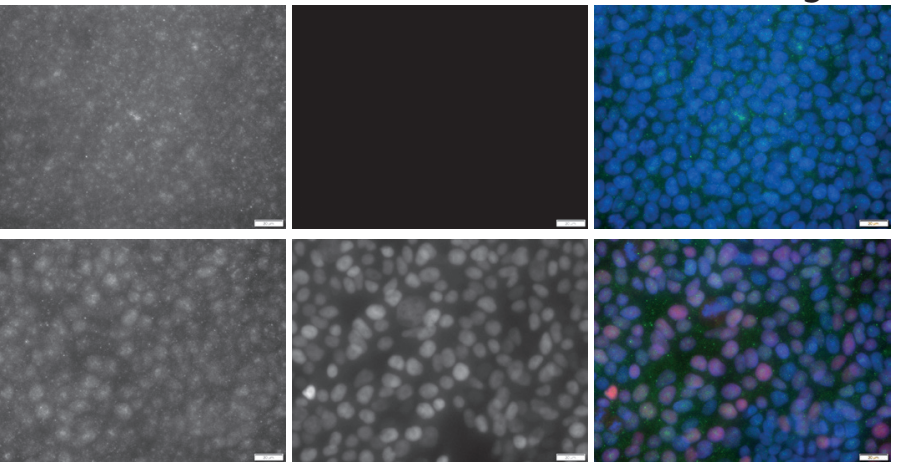
A.

/ 10.1101/2020-12.18.423466; this version posted December 18, 2020. The copyright holder for this preprint fwhich was not certified by peer reviews is the author/funder, who has granted bioRxiv a license to display the preprint in

\section{sest2 2}

U

$\mathrm{UI}$

+ Dox

UI

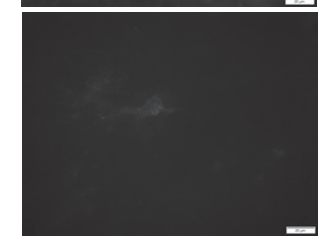

+ Dox
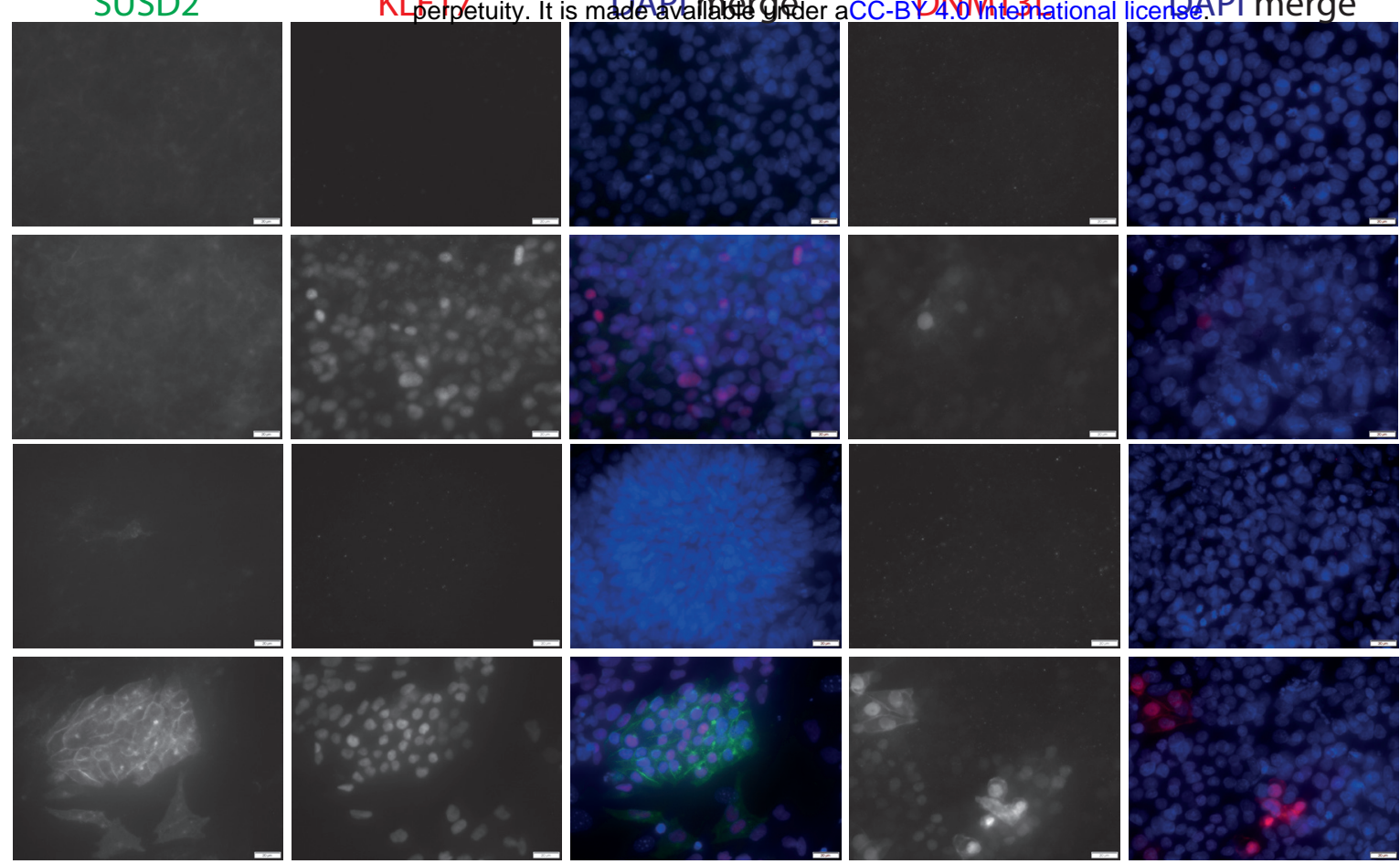

mTeSR

B.

$$
\text { p0 Day } 5
$$

$p+1$ 
A. bioRxiv preprint doi: https://doi.org/10.1101/2020.12.18.423466; this version posted December 18, 2020. The copyright holder for this gRNA Direction

\begin{tabular}{lll}
\hline KLF17(1_1) & Minus & 5'-GCCGTACATGAAGACTGGGT-3' \\
KLF17(1_2) & Minus & 5'-GGTCGGCCGTACATGAAGAC-3' \\
KLF17(2_1) & Minus & 5'-TGCGCTGGTGGCTCACGAGG-3'
\end{tabular}

KLF17(3_1) Plus 5'-TGAGCTTAGACGACATATGC-3'

KLF17(3_2) Plus 5'-ATGAGCTTAGACGACATATG-3'

KLF17(3_3) Plus 5'-GAGGCCATATTCTTGCAACT-3'

B.
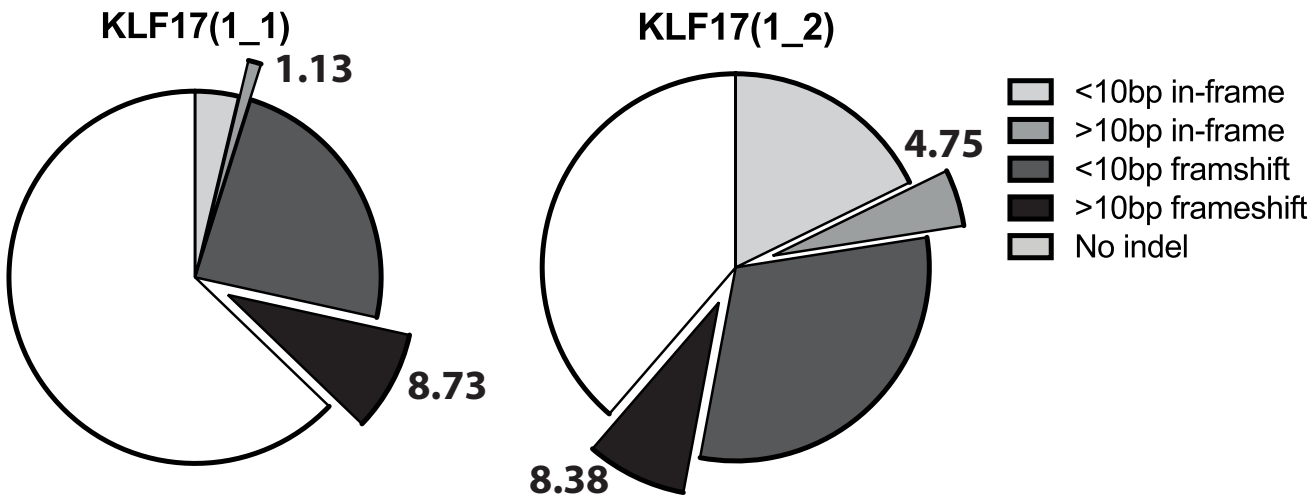

Total Indel Efficiency $(\%)=37.1875$ Total Indel Efficiency $(\%)=61.3366$ 
preprint (which was not certified by peer review) is the author/funder, who has granted bioRxiv a license to display the preprint in

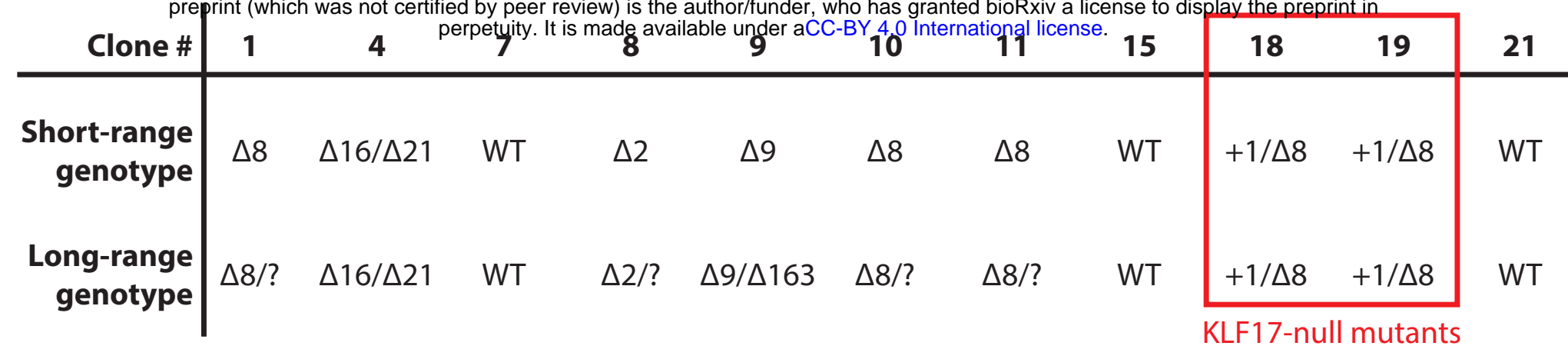

B.

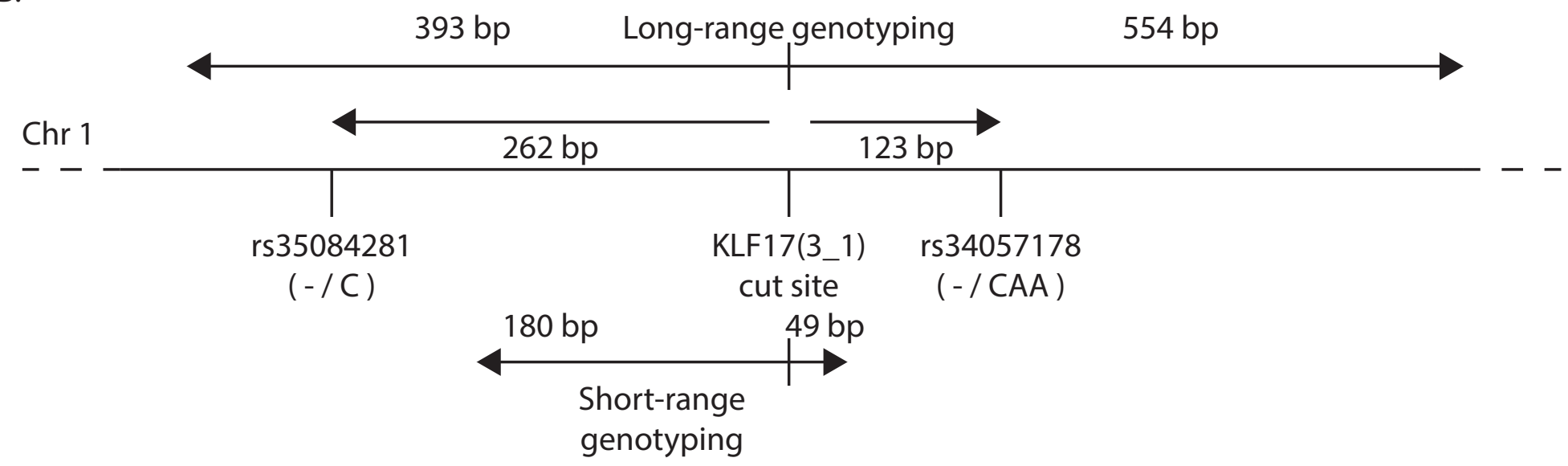

C.

\begin{tabular}{r|ccccccc} 
Cell Line & Parental H9 & \#7 & \#1 & \#8 & \#9 & \#10 & \#11 \\
\hline C / CAA & $53.85 \%$ & $37.5 \%$ & $0 \%$ & $0 \%$ & $29.17 \%$ & $0 \%$ & $0 \%$ \\
$-/-$ & $46.15 \%$ & $62.5 \%$ & $100 \%$ & $100 \%$ & $70.83 \%$ & $100 \%$ & $100 \%$
\end{tabular}

D.

$\begin{array}{lllllllllllllllllllllll}D & \mathbf{E} & \mathbf{L} & \mathbf{R} & \mathbf{R} & \mathbf{H} & \mathbf{M} & \mathbf{R} & \mathbf{V} & \mathbf{H} & \mathbf{T} & \mathbf{R} & \mathbf{Y} & \mathbf{R} & \mathbf{P} & \mathbf{Y} & \mathbf{K} & \mathbf{C} & \mathbf{D} & \mathbf{Q} & \mathbf{C} & \mathbf{S} & \mathbf{R}\end{array}$ GATGAGCTTAGACGACATATGCGGGTACACACCAGATATCGACCATATAAATGTGATCAGTGCAGCCGA $\mathrm{KLF17(3 \_ 1) \quad PAM}$

Reference target region

E.

$\begin{array}{lllllllllllllllllllllll}\mathbf{D} & \mathbf{E} & \mathbf{L} & \mathbf{R} & \mathbf{R} & \mathbf{H} & \mathbf{M} & \mathbf{R} & \mathbf{V} & \mathbf{H} & \mathbf{T} & \mathbf{R} & \mathbf{Y} & \mathbf{R} & \mathbf{P} & \mathbf{Y} & \mathbf{K} & \mathbf{C} & \mathbf{D} & \mathbf{Q} & \mathbf{C} & \mathbf{S} & \mathbf{R}\end{array}$ GATGAGCTTAGACGACATATGCGGGTACACACCAGATATCGACCATATAAATGTGATCAGTGCAGCCGA GATGAGCTTAGACGACATA - - - - - - CACACCAGATATCGACCATATAAATGTGATCAGTGCAGCCGA
D $\quad \begin{array}{llllll} & \mathbf{L} & \mathbf{R} & \mathbf{R} & \mathbf{H}\end{array}$ $\mathbf{T} \mathbf{H} \mathbf{Q}$ $\mathrm{HxnH}$ motif is disrupted Premature termination codons- third zinc finger is lost

F.

\begin{tabular}{lllllllllllllllllllllll}
$\mathbf{D}$ & $\mathbf{E}$ & $\mathbf{L}$ & $\mathbf{R}$ & $\mathbf{R}$ & $\mathbf{H}$ & $\mathbf{M}$ & $\mathbf{R}$ & $\mathbf{V}$ & $\mathbf{H}$ & $\mathbf{T}$ & $\mathbf{R}$ & $\mathbf{Y}$ & $\mathbf{R}$ & $\mathbf{P}$ & $\mathbf{Y}$ & $\mathbf{K}$ & $\mathbf{C}$ & $\mathbf{D}$ & $\mathbf{Q}$ & $\mathbf{C}$ & $\mathbf{S}$ & $\mathbf{R}$ \\
\hline
\end{tabular} GATGAGCTTAGACGACATA - TGCGGGTACACACCAGATATCGACCATATAAATGTGATCAGTGCAGCCGA GATGAGCTTAGACGACATAATGCGGGTACACACCAGATATCGACCATATAAATGTGATCAGTGCAGCCGA D $\quad \begin{array}{lllll}\mathbf{L} & \mathbf{R} & \mathbf{R} & \frac{\mathbf{H} \mathbf{N} \quad \mathbf{A} \quad \mathbf{G} \mathbf{T} \quad \mathbf{H}}{\mathrm{H} \times \mathrm{QnH} \text { motif is disrupted }}\end{array}$ $\begin{array}{lllllllllllllll}\mathbf{S} & \mathbf{T} & \mathbf{I} & * & \mathbf{M} & * & \mathbf{S} & \mathbf{V} & \mathbf{Q} & \mathbf{P}\end{array}$ +1 bp insertion Premature termination codonsthird zinc finger is lost 
A.

bioRxiv preprint doi: https Bdoi.org/10.1101/2020.12.18.423466; this@ersion posted December 18, 2020. The ED.pyright holder for this preprint (which was not certified by peer reviewy) is the author/funder, who has granted bioBx jv a license to display the preprint in
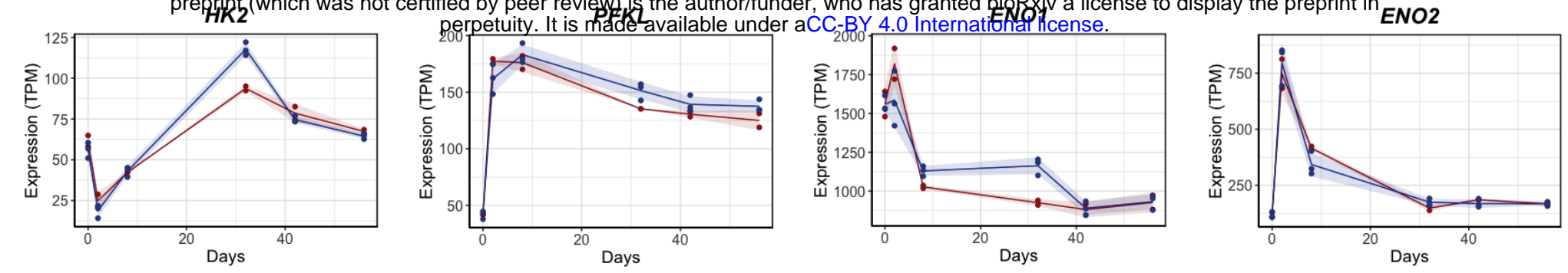

E.



F.

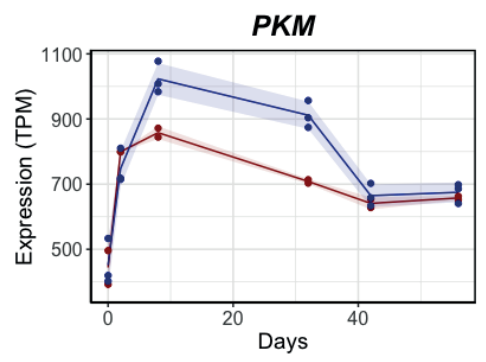

G.

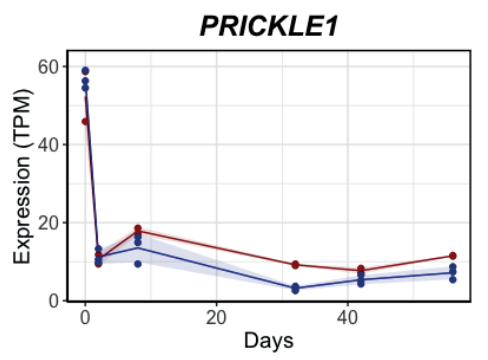

$\mathrm{H}$.

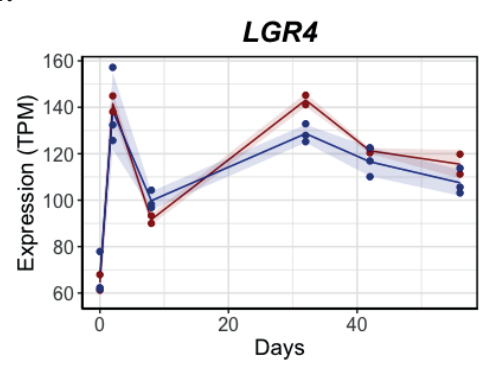

